\title{
İş Yükü Algısı ve İş Yükünün İnsan Kaynakları Yönetiminde Kullanımı: Eskişehir'de Otel İşletmeleri Örneği*
}

\author{
Workload Perception in Hotel Business and use of Workload in \\ Human Resources Management in Eskisehir
}

\author{
Arş. Grv. Ezgi Atik - Prof. Dr. Meryem Akoğlan Kozak
}

\begin{abstract}
Öz
Otel işletmelerinde çalışanların performansında iş yükü önemli bir faktördür. Aynı zamanda, iş yükünün yöneticiler tarafindan dikkate alınması insan kaynakları yönetimindeki birçok sorunun önlenmesine de katkı sağlamaktadır. Otel çalışan ve yöneticilerinin işyükü algılarının belirlenmesine yönelik hazırlanan bu çalışmada ayrıca, yöneticilerin insan kaynakları fonksiyonlarının yürütülmesinde iş yüküne verdikleri önem de belirlenmeye çalışılmaktadır. Çalışma, Eskişehir'de bulunan 23 otelden 262 çalş̧an ve 90 yönetici olmak üzere toplam 352 çalışanın katılımı ile gerçekleştirilmiştir. Verilerin toplanmasinda, anket tekniğinden yararlanılmışır. Elde edilen veriler; faktör analizi, bağımsız örneklem $T$ testi, tek yönlü varyans analizi (ANOVA) ve Pearson korelasyon analizi ile test edilmiştir. Araştırmada; çalş̧̧an ve yöneticilerin iş yükü algilarının, fiziksel, zihinsel, konumsal, çevresel ve duygusal olmak üzere toplam beş faktörden oluştuğu belirlenmiştir. Çalışanların ve yöneticilerin demografik özellikleri ile iş yükü algıları arasında eğitim durumu, departman, yaş ve iş tecrübesi açısından anlamlı ilişkiler tespit edilmiştir. Çalışanlarm ve yöneticilerin genel iş yüküne ilişsin algılamalarının ise orta düzeyde olduğu belirlenmiștir. Ayrıca, yöneticilerin insan kaynakları yönetimi ile ilgili faaliyetleri yürütürken iş yüküne en fazla planlama ve kariyer yönetimi fonksiyonlarında önem verdiklerine yönelik bulgulara da ulaşılmıştır.
\end{abstract}

Anahtar Kelimeler: İnsan Kaynakları Yönetimi Fonksiyonları, İş Yükü, İş Yükü Modelleri, Otel İşletmeleri, Eskişehir.

\begin{abstract}
Workload is an important factor at staff's performan$c e$ in hotels. At the same time, manager's workload consideration prevents lots of human resources management problems. This research prepared to analyse staff's perception about workload. It also aimed to detect manager's consideration about workload when they performed human resources management functions. The research performed with 28 hotels and 352 staff (262 worker and 90 manager) in Eskişehir. In the reseach, survey technique used for collecting data. Data are tested with factor analysis, independent sample $T$ test, one-way variance analysis and Pearson corelation analysis. In research, staff's workload determined with five factors: physical, mental, positional, environmental and emotinal. Positional factors was found primary factors at workload perception. It determined relations between staff's demographic characteristics and workload perception in terms of educational status, department, age and work experience. Workers' and managers' general workload perception found at average levels. Also, findings show that in human resources, managers primarily consider workload in planning and career managing.
\end{abstract}

Keywords: Human Resources Management Functions, Workload, Workload Models, Hotels, Eskişehir.

Arş. Grv. Ezgi Atik, Anadolu Üniversitesi Eskişehir MYO, easar@anadolu.edu.tr

Prof. Dr. Meryem Akoğlan Kozak, Anadolu Üniversitesi İşletme Fakültesi, mkozak@anadolu.edu.tr

* Bu çalışma Anadolu Üniversitesi Sosyal Bilimler Enstitüsü Turizm İşletmeciliği ABD’ında hazırlanan yüksek lisans tezinden türetilmiştir. 


\section{Giriş}

Emeğin yoğun olduğu ve işletme başarısının insan kaynağ 1 ile ilişkilendirildiği otel işletmelerinde sektörel birtakım olumsuz özellikler çalışanların performanslarını etkilemektedir. İnsan kaynakları yönetimi ile ilgili literatürde çalışanların performanslarının insan kaynakları fonksiyonları, örgütsel bağlılık, motivasyon, stres, tükenmişlik ve sinism gibi konular kapsamında incelendiği görülmektedir. Ancak çalışan performansı ile yakından ilişkili konulardan biri olan iş yükü konusu, insan kaynakları yönetiminin tüm fonksiyonları açısından önemlidir. Havacılık ve eğitim gibi diğer sektörlerde yapılan çalışmalar, çalışanların iş yükü algılarının önemini ortaya koymakta iken; otel işletmelerinde bu konunun doğrudan bir faktör olarak ele alınmadığı görülmektedir.

İlgili literatürdeki bu eksiklikten yola çıkılarak gerçekleștirilen bu çalışmanın amacı, otel çalışan ve yöneticilerinin iş yükü algılarını ve yöneticilerin yürüttükleri insan kaynakları fonksiyonlarında iş yükünü dikkate alıp almadıklarını belirlemektir. Otel işletmelerinde çalışanların performanslarına etki eden iş yükü faktörlerinin bilinmesi ve aynı zamanda insan kaynakları yönetiminde iş yüküne verilen önemin belirlenmesi ile işletme içerisindeki insan kaynağı ile ilişkili sorunların çözülebileceği düşünülmektedir. Çalışmanın, literatüre olduğu kadar otel yöneticilerine de iş yükü konusunun insan kaynakları yönetimi ile ilgili konularda daha fazla kullanımı açısından katkı sağlayacağı düşünülmektedir. Bu bağlamda çalışmada ilk olarak iş yükü ile ilgili ve insan kaynakları yönetiminde iş yükünün kullanımı ile ilgili literatüre yer verilmiş, daha sonra araştırma metodolojisine değinilmiş ve devamında araştırma bulguları açıklanmıştır. Sonuç bölümünde çalışmada elde edilen bulgular ilgili literatür bağlamında değerlendirilmiştir.

\section{Literatür}

\section{Iş̧ Yükü Kavramı}

Otel işletmelerinde genellikle, soyut, ayrılmaz, değişken ve depolanmayan hizmetler üretilmektedir. Hizmetlerin sunumunda işin gereği olarak insan gücünden yararlanılmaktadır. Bu nedenle işletmelerin başarısında en önemli unsur çalışan ve yöneticilerin performansı olmaktadır. Yapılan çalışmalar (Charles ve Marshall, 1992; Casado, 1992; Christou, 1999; Duman vd., 2006; Kaya, 2012; Saldamlı, 2013) otel işlet- melerinde çalışanların en faza hakkettikleri ücreti alamama, motivasyon eksikliği yaşama, uzun çalışma saatleri, niteliksiz işlerde çalıştırılma ve aşırı iş yükü gibi sorunlarla karşılaştıklarını ortaya koymaktadır. Otel işletmelerinde insan kaynakları yönetiminde yaşanan önemli sorunlardan biri olarak gösterilen iş yükü kavramının, bu nedenle tanımlanması ve gelişiminin detaylı ele alınmasının gerektiği düşünülmüştür.

Weiner 1982 yılında yaptığı tanımda iş yükünü 'bir çalışanın iş performansına ve işe yönelik tepkilerine etki eden çeşitli baskılar' olarak ifade etmektedir (aktaran Öğrüç Ildız, 2009, s.33). Hart ve Staveland’a göre (1988) iş yükü, bir görevin gerekleri ile performans, beceriler, davranışlar ve çalışanın algılama koşulları arası oluşan etkileşimdir. Kramer ise bir çalışanın tanımlanmış bir görevi yaparken katlandığı 'maliyeti' iş yükü olarak tanımlanmaktadır (Kramer, 1991). Ordukayàya göre iş yükü $(2011$, s. 214) çalışana verilen görevin niteliği ile gösterdikleri performans arasındaki uyumsuzluğun yol açtığı bir alg1dır. Çelik ve Çıra ise $(2013$, s.11) iş yükünü 'bireyin kendisine yüklenen işin normalin üzerinde olduğuna yönelik algısı' şeklinde tanımlamaktadır. Genel olarak değerlendirildiğinde, iş yükü ile ilgili tanımların görev isteği, performans düzeyi, çaba ve algılamalar üzerinde yoğunlaştı̆̆ 1 görülmektedir. Tanımlardan da anlaşılabileceği gibi iş yükü bir yandan çalışanın algılaması ile ilişkili iken diğer yandan çalışanın yaptığı iş ile de doğrudan ilişkilidir. Bu durum, fiziksel ve zihinsel yetenekleri birbirinden farklı olan çal1şanların iş ile uyum sağlamalarını gerektirmektedir. Bunun nedeni, kişilerin yetenekleri doğrultusunda gösterdikleri performanslar, işin ortalama çalışma süresi ile uyumsuz ise çalışanda aşırı iş yükü algısının oluşmasıdır (Ordukaya, 2011, s. 214).

\section{İş Yükünün Gelişim Süreci}

İş yükü ile ilgili yapılan çalışmaların bilimsel yönetim yaklaşımı dönemine kadar uzandığı söylenebilir. Bu dönemde yapılan standartlaştırma, iş bölümü, görev ayrımı, ödül sistemi gibi birtakım uygulamalar iş yükünün gelişimine önemli zemin oluşturmuştur. Otel işletmelerinde bu kapsamda yapılan ilk uygulama Statler tarafından 1908 tarhinde gerçekleştirlmiştir. Statler, bu bağlamda, merkezileşmiş otoriteyi ve iş standartlarını geliştirerek işletmesini zincir otel haline getirmiştir (Akoğlan Kozak, 2009, s.10). Diğer bir örnek, 1948 yllında Sherman otelde uygulanan iş analizi çalışmalarıdır. Burada ise oda temizliğine 
ilişkin tüm süreçler zaman ve mesafe bakımından yeniden düzenlemiştir. 1940 yllında Stouffer kardeşler tarafından geliştirilen mutfak işleri için standart reçeteler getirilmesi, benzer işleri bir araya getirilmesi ve çalışanların iş gereklerine göre eğitilmesi süreçleri ise restoranlar için ilk örnektir (Olalı vd., 1989, s.205). Otellerde yapılan tüm bu çalışmaların sonraki yıllarda iş yükü ile ilgili yapılan çalışmalara dayanak teşkil ettiği söylenebilir. Doğrudan iş yükü kavramına yönelik ilk çalışmalar ise 1960 'larda başlamıştır. Hicks (1960, s.5-9) fakülteler kapsamında yaptığ çalışmasında, iş yükünü eğitim maliyeti yaratan bir unsur olarak tanımlamış ve iş yükünün fakülte çalışanlarının performansı ile ilişkilendirilebileceğini vurgulamıştır. Daha sonra ise Stecklin (1974) bu çalışmadan yararlanarak iş yükünün, ders içerikleri, çalışma saatleri ve fakülte envanteri ile ilgili belirleme çalışmalarında kullanılabileceğini ortaya koymuştur. 1960'larda sadece fiziksel iş yükünün belirlenmesi ve ölçümüne yönelik çalışmalar 1980'lere doğru zihinsel iş yükünün de olduğunun tespit edilmesi ile (Mulder, 1979; Sheridan ve Stassen 1979; Ursin ve Ursin 1979; Sheridan, 1983) değişim göstermiştir. Zihinsel iş yükünün belirlenmesine yönelik ilk çalışmalar 1970'li yıllarda pilotlar üzerine yapılmış ve bu çalışmalarda pilotların zihinsel iş yükleri belirlenmeye çalışılmıştır (Krol, 1971; Roscoe, 1978; Sheridan ve Simpson, 1979; Wierwille, 1979).

Hizmet sektöründe ise iş yükü konusu en fazla sağlık sektöründe ele alınmıştır. Çalışmalarda çalışanların iş yükü algıları (Gertsch, 1987; Cobb vd., 1989), iş yükünün oluşum nedenleri (Newton vd., 1994; Gillison vd., 2002) ve etkileri (Lowy vd., 1993; Sainsbury vd., 1995) incelenmiştir. Çalışmalar sonucunda iş yükünün en önemli etkisinin çalışan hatalarını artırması ve buna bağlı olarak sağlık sektöründe sorunlar gelişebileceği belirlenmiştir.

Otel işletmelerinde yapılan çalışmalarda, iş yükü algısı ile işlerin fazlalığı, yorgunluk, tükenmişlik, stres gibi işletme içi nedenlerin ilişkisi incelenmektedir. Tükenmişlik ile ilgili yapılan bazı çalışmalarda (Brymer vd., 1991; Zohar, 1994; Akoğlan Kozak, 2001; Tepeci ve Birdir, 2003; Bahar, 2006; Bolat, 2011) tükenmişlik sebebi olarak ağır çalışma şartlarının olduğu ve bu durumun da iş yüküne neden olduğu belirlenmiştir. Bazı çalışmalarda ise (Akçadağ ve Özdemir, 2005; Keser, 2006; Toker, 2011) iş yükünün stresi artırdığ 1 ve tükenmişliğe neden olabileceği konusu üzerinde durulmaktadır.

\section{İş Yüküne Etki Eden Faktörler}

Ergonomide, iş yükü konusu fiziksel faktörler, zihinsel faktörler, çevresel faktörler ve konumsal faktörler olmak üzere dört başlık altında incelenmektedir (Şimşek, 1994; Su, 2001; Dağdeviren vd., 2005; İncir, 2008; Gawon, 2008). İş yükü kapsamında önemli olan fiziksel faktörler; yükün ağırlığı, taşıma frekansı, taşıma süresi ve taşıma mesafesine bağlı olarak değişen (Cooper ve Harper, 1969; Wolf, 1978; Saaty, 1980) iş yükünün fiziksel güce bağlı olan kısmıdır. Otel İşletmelerinde iş ve işletme ile ilgili faktörlerin işgören tatmini üzerindeki görece etkisinin araştırıldığı bir çalışmada (Kuşluvan ve Kuşluvan, 2005) fiziksel çalışma ortamlarının işe uygunluğunun işgören tatmini olumlu yönde etkilediği belirlenmiştir. Otel işletmelerinde ve iş koşullarının çalışanlara fiziksel olarak etkisinin belirlendiği bir başka çalışmada ise (Krause vd., 2005), çalışanların \%47'sinin genel anlamda, \%3'ünün ise özellikle ayaklarında acı hissettiği ve ayrıca çalışanların yaklaşık dörtte üçlük kısmının aşırı fiziksel iş yükü algıladığı belirlenmiştir.

Zihinsel iş yükü faktörleri ise hesaplama, karar verme ve iletişim kurma gibi zihinsel faaliyetlerin yerine getirilmesi sürecinde algılanan iş yüküne bağlı faktörler (Caplan, 1971; Helm ve Donnel, 1979; Pulat, 1997; Duru vd., 2005) olarak ifade edilebilir. Örgütsel stres ve örgütsel bağlllık ilişkisi üzerine orta kademe otel yöneticileri üzerinde yapılan bir araştırmada (Uzun ve Yiğit, 2011) iş yükü algısı, zihinsel stres yaratan bir unsur olarak nitelendirilmiş ve yöneticilerde iş yükünün azaltıması gerektiği üzerinde durulmuştur.

Sıcaklık, aydınlatma, gürültü, titreşim, toz ve gaz gibi bazı zararlı maddeler ise çalışma ortamında olumsuzluk yaratan çevresel iş yükü faktörleridir (Adalı, 1980; Osmay, 2005; Guastello, 2006). Otel mutfaklarında yapılan bir çalışmada (Kalınkara ve Öktem, 2002) çalışanların mutfaklarda havalandırma, sıcaklık, cereyan, nem ve gürültü gibi unsurlardan fazla etkilenmedikleri ortaya çıkmıştır.

Diğer bir faktör olan konumsal faktörler ise vücut duruşlarına bağlı olarak gelişen, vücut hareketlerinin tersliği ve elverişsiz konumdan dolayı algılanan (Saaty, 1980; Finegold vd., 1986; Vidulich ve Tshang, 1987) iş yükü faktörleridir. Aşçıların tezgah başındaki duruşlarının gözlemlendiği bir çalışmada (Iwakiri vd., 2008) uzun süre çalışanlarda duruşa bağlı rahatsızlıkların oluştuğu belirlenmiştir. 
Tüm bunlara ek olarak oteller bağlamında yapılan çalışmalar (Kim, 2008; Akoğlan Kozak ve Güçlü Nergiz, 2008; Türkay vd., 2012) otel çalışanlarının hizmet üretimi ve sunumunda duygusal çaba da gösterdiklerini de ortaya koymaktadır. Dolayısyla, hizmet sektöründe müşteri ile yüzyüze gerçekleştirilen bir çok işte çalışanaların daha önce belirlen dört faktör yanında, duygusal olarak iş yükü algılayabilecekleri söylenebilmektedir. Duygusal çaba (Morris ve Feldman, 1996, Seymour, 2000; Grandey, 2003); yüzeysel davranış, derin davranış, samimi davranış, duyguları yansıtma ve görünüm kurallarından oluşmaktadır. Bu boyutlar, çalışanların daha çok duygularıyla başetmesiyle ilgili olup, iş yükü algısına sebep olmaktadır. Bu bağlamda, otel çalışanlarının daha çok stres altında oldukları (Toker, 2011; Saldamlı, 2013) ya da tükenmişlik sendorumuna yakalandıkları ( Tepeci ve Birdir, 2003; Bolat, 2011) örnek olarak verilebilir.

\section{İnsan Kaynakları Fonksiyonları ve İş Yükü Kullanımı}

Otel işletmelerinde çalışanların çalışma alanı ve müşterilerin kullanım alanlarının aynı olması, otel işletmelerinde insan kaynağ $\breve{1}_{1}$ unsurunu daha da önemli kılmaktadır (Özel, 2012, s. 14). Bir başka ifade ile 'hizmet işletmelerinde çalışan bir başarı ve kalite faktörü olarak görülmektedir' (Akoğlan Kozak, 2012, s. 57). Ancak, çalışanların başarısını etkileyen birçok unsur bulunmaktadır. Sezonluk yoğunluk, 7/24 çalışma koşulları gibi birtakım olumsuzluklar, otel işletmelerinde insan kaynakları yönetiminde sorunlar oluşturmaktadır. Aynı zamanda bu sorunlar çalışanlarda iş yükü algısını da artırabilmektedir. Bu nedenle, çalışanlarda fazla iş yükü baskısını azaltmak için insan kaynakları yöneticilerine önemli görevler düşmektedir (Baum, 2006). İş yükü konusu başta insan kaynakları planlaması olmak üzere iş değerleme, performans değerleme ve ücret yönetimi ile iş güvenliği ve sağlığı konuları açısından değerlendirilebilmektedir (Tortop vd., 2007; Dolgun, 2010; Can vd., 1998; Mirze, 2010).

İnsan kaynakları planlaması temelde doğru sayıda ve doğru nitelikte çalışanın belirlenmesinden oluşmaktadır (Mirze; 2010, s. 174). Doğru nitelikte çalışanın belirlenmesi aşamasında ise iş yükü değerleme konusu da ele alınmaktadır. Diğer bir deyişle işletmelerde her iş farklı bir yüke sahiptir ve doğru iș tanımlarıyla standardize edilmiş işler, karmaşık ve tanımlanmamış işlere oranla daha az yüke sahiptir. Diğer yandan, insan kaynakları planlamasında iş yükü konusu, planla- manın ikinci aşaması olan mevcut insan kaynaklarının değerlendirilmesi ve gelecekteki insan kaynakları ihtiyacının tahmin edilmesi aşamasında da açıklanmaktadır (Barutçugil, 2004; Demir ve Güzel, 2005, s. 65). Bu kapsamda çalışan gereksinimi, toplam iş yükü bireysel iş yüküne bölünerek hesaplanmaktadır (Kaynak, 1996, s. 124). Otel işletmelerinde planlama ile ilgili yapılan bir çalışmada, konaklama işletmelerinde planlama uygulamaları yapıldığı belirtilmesine rağmen uygulamada bu duruma rastlanmadığ (Akbaba ve Günlü, 2009) belirlenmiştir. Bir başka çalışmada ise (Zhang ve Wu, 2004) otellerdeki planlama ile ilgili zorluklara operasyonel ve yönetsel düzeydeki hatalı kadrolamaların, yüksek insan kaynağı devir oranlarının, üniversite mezunlarının isteksizliğinin, nitelikli insan kaynağı eksikliğinin, okullar, üniversiteler ve oteller arası eğitim farklılıklarının neden olduğu belirlenmiştir.

İş değerlemeye ilişkin bakış açısı 'eşit işe eşit ücret' ve 'işe göre çalışan' olmak üzere iki temel grup içerisinde ele alınmaktadır (Uyargil vd., 2008, s. 346). İş değerleme uygulamalarının başarısının ise çalışanların iş tatmini ve üretkenliklerini artırdığ 1 ve dolaylı olarak iş yükünü azaltabileceği düşünülmektedir (Dolgun, 2003, s. 203). Aynı zamanda iş değerleme sonucunda işe ilişkin yetki ve sorumlulukların belirlenmesi durumu, çalışanda 'belirgin olmayan görev yüklenimi' sorunundan doğan iş yükü algısını da azaltabilecektir (Keser, 2006, s. 106). İş değerleme konusunda beş yıldızlı bir otelde yapılan çalışmada (Kurgun ve Alimanoğlu Yemişçi, 2007) puanlama yönteminin uygulanabilirliği test edilmiştir. Çalışmada alt faktörlerden biri olarak değerlendirilen çaba faktörünün iş yükü ile ilgili çalışmalarda da ele alınan fiziksel ve zihinsel çaba olduğu belirlenmiştir.

Performans değerleme ve iş yükü algısı konusu farklı şekillerde değerlendirilmektedir. Bir görüşe göre (Karakuş ve Kılınç, 2006, s. 310) performans geliştirilebilir özellikte olmasına karşın kişilerde performansı karşılayabilecek direnç oluşmadığ 1 durumda performans kapasitesi azalmaktadır. Bir başka deyiş̧le performans kapasitesinin yetmediği durumlarda çalışanlarda iş yükü algısı oluşabilmektedir. Diğer bir görüşe göre ise işletmelerin başarısı insan kaynağının performans olarak yeterliliği ve işe uyumu ile ilişkilendirilmektedir (Luecke, 2010). Yani, insan kaynağının işletmeye fayda sağlaması, performansları ve yetenekleri doğrultusunda gerçekleşmektedir. Ancak, çalışan yeteneklerine ve becerilerine uygun 
işlerde çalışmadığı zaman, iş yükünde artış olduğunu hissedebilmektedir. Çalışan performansında iş yükünün etkilerini araștırdığı bir çalışmada (Turhan, 2001), hava trafik kontrolörlerini en fazla etkileyen faktörlerden olan iş yükü incelenmiș ve mesleğin niteliğinin algılanan iş yükünü artırdığı ve iş yükünün çalışanlarda strese neden olduğu ortaya çıkmıştır. Diğer yandan otel işletmelerinde yapılan çalışmalarda performans sistemi uygulayan otellerin daha başarılı olduğu (Bergin-Seers ve Jago; 2007), performans değerleme sonuçlarının ücret ve kariyer konularında yeterince dikkate alınmadığ 1 (Gavcar vd., 2006; Esmer, 2011) ve otel işletmelerinde performans değerleme sistemlerinin gerekli olduğu (Arslantürk, 2009) sonuçları ortaya çıkmıştır.

Kariyer yönetimi fonksiyonu ise hem çalışan hem de işletmeyi ilgilendiren bir faktör olarak, çalışanların etkin ve verimli çalışmalarını etkilemektedir. Kariyer planlama bir yandan çalışanın gelecekle ilgili beklentilerine karşılık veren bir sistem olarak birey üzerinde olumlu etki yaratırken; diğer yandan bu konudaki engeller çalışanları olumsuz olarak etkileyebilmektedir (Akoğlan Kozak, 2009, s. 88). Otel işletmelerinde kariyer yönetimi ile ilgili çalışmalar kariyer geliştirme (Ng ve Pine, 2003), örgütsel bağlılık ve kariyer ilişkisi (Kılıç ve Öztürk, 2010), kariyer planlama (Akoğlan Kozak, 1999), kariyer yolları (Ladkin ve Riley, 1996) ve kariyer engelleri (Aydın Tükeltürk ve Şahin Perçin, 2008) üzerine yapılmıştır. Kariyer engelleri olarak tükenmişlik, gözden düşme, cam tavan, beceri eksikliği, cinsel ayrımcılık, çift kariyerli eşler ve ikinci iş olarak adlandırılan etmenler, aynı zamanda çalışanlarda iş yükünü artırabilecek birer olumsuz durum olarak da görülebilmektedir.

Benzer şekilde ücret yönetimi konusu da iş yükü ile yakından ilişkili olan bir insan kaynakları yönetimi fonksiyonu olarak değerlendirilebilir. Otel işletmelerinde yapılan çalışmalar (Kuşluvan ve Kuşluvan, 2005; İnce, 2008; Tuncer ve Yeşiltaş, 2013) çalışanların ücret konusunda sorunlar yaşadıklarını göstermektedir. Ücret yönetimi kapsamında iş yükü konusu ücretin oluşumunu etkileyen iç unsurlardan olan 'insan kaynağının bilgi, beceri ve yetkinlikleri ile insan kaynağının performansı ve kıdem' konuları ile ilişkilendirilebilmektedir (Dolgun, 2010, s. 200). Bu kapsamda yetkinlikleri diğer çalışanlara göre fazla olan kişiler, iş yüklerindeki artıșa bağlı olarak bu oranda ücret bekleyeceklerdir. Diğer yandan fazla performans gös- teren çalışan da diğer çalışana göre daha fazla iş yükü üstlendiğini düşüneceğinden ücretlendirmenin bu oranda artışını bekleyecektir.

İş güvenliği fonksiyonu bağlamında ise özellikle iş kazaları ve işçi sağllğı konuları iş yükü konusu ile ilişkilendirilebilmektedir. İş kazaları ve çalışan sağl1ğını bozan etmenler olarak sıralanan sıcak ve nemli ortamda çalışma, yetersiz ışılklandırma, gürültü, gece vardiyaları gibi birtakım çevresel etmenler (Bilgin, 1994; Camkurt, 2007) aynı zamanda iş yükü ile ilgili çalışmalarda (Saaty, 1980; Finegold vd., 1986; Sağın, 1986) iş yükünü artıran unsurlar olarak da değerlendirilmektedir. Bu durumda, iş güvenliği ile ilgili unsurlardaki olumsuzlukların çalışanlarda iş yükü algısı yaratabileceği söylenebilir.

İş yükü konusu literatürde son olarak çalışan ilişkileri kapsamında ele alınan stres, tükenmişlik ve motivasyon konuları ile ilişkilendirilmektedir. Yapılan çalışmalar sonucunda artan iş yükü algısının çalışanlarda stres ve tükenmişlik durumunu artıracağ lürken (Bolat, 2011; Uzun ve Yiğit, 2011; Saldaml,, 2013); aynı zamanda çalışanda algılanan motivasyon eksikliklerinin de (Akçadağ ve Özdemir, 2005; Keser, 2006; Toker, 2011) iş yükü algısını artırabileceği belirlenmiştir.

\section{İş Yükü Ölçüm Modelleri}

İş yükü algısı, otel işletmelerinde planlama, iş değerleme, performans ve kariyer gelişimi, ücret yönetimi gibi birçok insan kaynakları fonksiyonunun doğru olarak yürütülmesinde önemli bir etmendir. Bu nedenle, çalışanların iş yüklerinin hangi faktörlerden oluştuğunun bilinmesi ve sonuçlara göre gerekli düzeltmelerin yapılması önemlidir. Çalışanların iş yükünü belirlemeye yönelik modellerin fizyolojik (matematiksel) ve algısal olmak üzere iki temel ayrımda açıklandığı görülmektedir.

Fizyolojik ölçüm modelleri, 'çalışanların iş yapma esnasında gösterdikleri fiziksel reaksiyonları ölçmeye dayalı' tekniklerdir (Miller, 2001, s. 6). Fizyolojik iş yükü modelleri ile ilgili ilk çalışma Meister (1986) tarafından, kalp atış hızı ve tansiyon gibi kalp ile ilgili göstergeler doğrultusunda gerçekleştirilmiştir. Daha sonraki çalışmalarda ise solunum ile ilgili modeller (Roscoe, 1992), konuşma ile ilgili modeller (Brenner vd., 1994), beyin faaliyetleri ile ilgili modeller (De Waard, 1996) ve gözler ile ilgili modeller (Brookings 
vd., 1996) geliştirilmiştir. Bu çalışmalarda genel olarak çalışanın vücuduna yerleştirilen birtakım teknik ekipmanlarla laboratuvar ortamında veya çalışanın iş yapması esnasında fiziksel ve zihinsel iş yüklerine ilişskin sayısal sonuçlar elde edilmektedir.

Diğer yandan, algısal ölçüm modelleri ise çalışanların zihinlerinde algıladıkları iş yükü ile ilgili bilgileri belirlemeye yönelik geliștirilmiș modellerdir (Yeh ve Wickens, 1988). Algısal ölçüm modellerinde çalışanların bireysel alg1, tutum ve yeteneklerine yer verildiğinden (Muckler ve Seven, 1992) bu modellerle, otel işletmeleri gibi birçok departman ve birbirinden farklı işlerin olduğu işletmelerde de her farklı çalışan için ayrı ayrı iş yükünü ortaya çıkarabilmek mümkün olabilmektedir. Algısal ölçüm modelleri ile yalnız zihinsel iş yükü (Shreidan ve Simpson, 1979; Roscoe, 1984; Wierwille vd., 1985) veya yalnız fiziksel iş yükü (Cooper ve Harper, 1969) ölçülebildiği gibi, birçok faktörün bir arada (Saaty, 1980; Hart ve Hauser, 1987; Hart ve Staveland, 1988) ya da yalnızca genel iş yükü algisının (Vidulich ve Tsang, 1987; Lysaght vd., 1989) ölçülebildiği bilinmektedir. Otel işletmeleri açısından, iş yükü ölçümüne yönelik oluşturulmuş modeller incelendiğinde ve iş yükünü oluşturan faktörlerin fazlalığı da dikkate alındığında, iş yükü algısını belirlemede yalnız fiziksel iş yükünü veya yalnız zihinsel iş yükünü ölçen tek bir ölçeğin uygulanmasının eksik kalacağı görülmüştür. Bu nedenle çalışmada literatürden yararlanılarak yeni bir karma ölçeğin oluşturulmasına çalışılacaktır. Bu amaçla, oluşturulan metodolojiye araştırma kısmında detaylı şekilde yer verilmiştir.

\section{Araştırma Metodolojisi}

Çalışmanın iki ana amacı, çalışanların ve yöneticilerin iş yükünü nasıl algıladıklarını belirlemek ve yöneticilerin insan kaynakları yönetiminde iş yüküne verdikleri önemi ortaya koymaktır. Bu amaçlar doğrultusunda gerçekleştirilen çalışmada Eskişehir'deki Turizm İşletme Belgeli 28 konaklama işletmesinde çalışan toplam 676 çalışan araştırma evreni olarak belirlenmiştir. Araştırmaya katılmayı kabul eden 24 otel işletmesinden 262 çalışan ve 90 yönetici olmak üzere 352 çalışan ile çalışma gerçekleştirilmiştir. Bu sayı genelin $\% 52$ 'sini temsil niteliğindedir.

Çalışmaya anket soru formu hazırlanarak başlanmıştır. Anket soru formu çalışanlara ve yöneticilere ayrı ayrı olmak üzere iki kısımdan oluşmaktadır. Soru formunun birinci bölümünde algisal ölçüm modellerindeki faktörlerden yararlanılarak dört faktör belirlenmiştir. Bunlar; fiziksel iş yükü, zihinsel iş yükü, çevresel iş yükü ve konumsal iş yüküdür. Ayrıca, hizmet sektöründe önemli bir bileşen olan ve otellerde iş yü-

Tablo 1. İ̧ Yükü ile İlgili ifadelerin Oluşturulmasında Yararlanılan Çalışmalar

\begin{tabular}{|l|l|}
\hline İş Yükü Faktörleri & İlgili Çalışmalar \\
\hline Duygusal Çaba Faktörleri & $\begin{array}{l}\text { Hochschild, 1983; Rafaeli ve Sutton, 1987;Ashforth ve Humphrey, 1993; Morris ve } \\
\text { Feldman, 1996; Seymour, 2000; Grandey, 2003; Akoğlan Kozak ve Güçlü, 2008. }\end{array}$ \\
\hline Fiziksel Faktörler & $\begin{array}{l}\text { Pearson ve Byars, 1956; Cooper ve Harper, 1969; Caplan, 1971; Wolf, 1978; Saaty, } \\
\text { 1980; Shachem, 1983; Wierwielle ve Casali, 1983; Roscoe, 1984; Wierwille, Rahimi } \\
\text { ve Casali, 1985; Finegold vd., 1986; Hart ve Hauser, 1987; Vidulich ve Tshang, 1987; } \\
\text { Hart ve Staveland, 1988; Pitrella ve Kapler, 1988; Lysaght vd., 1989; Şimşek, 1994; } \\
\text { Su, 2001. }\end{array}$ \\
\hline Zihinsel Faktörler & $\begin{array}{l}\text { Caplan, 1971; Helm ve Donnel, 1979; Sheridan ve Simpson, 1979; Saaty, 1980; } \\
\text { Wierwielle ve Casalli, 1983; Roscoe, 1984; Wierwille, Rahimi ve Casali, 1985; } \\
\text { Finegold vd., 1986; Hart ve Hauser, 1987; Vidulich ve Tshang, 1987; Hart ve } \\
\text { Staveland, 1988; Şimşek, 1994; Pulat, 1997; Duru vd., 2005; Erkan, 2005; Osmay, } \\
\text { 2005; Guastello, 2006. }\end{array}$ \\
\hline Çevresel Faktörler & $\begin{array}{l}\text { Adalı, 1980; Saaty, 1980; Finegold vd., 1986; Sağın, 1986; Vidulich ve Tshang, 1987; } \\
\text { Şimşek, 1994; Su, 2001; Kalınkara ve Öktem, 2002; Erkan, 2005; Incir, 2008. }\end{array}$ \\
\hline Konumsal Faktörler & $\begin{array}{l}\text { Saaty, 1980; Finegold vd., 1986; Vidulich ve Tshang, 1987; Özkul, 1996; Messing, } \\
\text { Chatignya ve Courvillea, 1998; Kalınkara ve Öktem, 2002; Dağdeviren vd., 2005; } \\
\text { Iwakiri vd., 2008; Jing vd., 2009; Çekal, 2013. }\end{array}$ \\
\hline
\end{tabular}


künü etkileyebilecek bir etmen olarak duygusal çaba faktörü de araştırmaya dahil edilmiştir. Bu boyutlarla ilgili literatür bilgilerine Tablo l'de yer verilmektedir.

Soru formunun ikinci bölümünde ise yöneticilerin insan kaynakları yönetimi ile ilgili iş yükü algılarının ölçülmesine çalışılmaktadır. Bu amaçla, literatürden sağlanan insan kaynakları yönetimi ile ilgili olarak yedi faktör belirlenmiştir. Bunlar; insan kaynakları planlaması, iş değerleme, performans değerleme, $k a-$ riyer yönetimi, ücret yönetimi, iş güvenliği ve çalışan ilişkileridir. Bu amaçla yararlanılan çeşitli kaynaklar Tablo 2'de gösterilmektedir.

Tablo 2. Insan Kaynakları Yönetimi Faktörleri ile Ilgili ifadelerin Oluşturulmasında Yararlanılan Çalışmalar

\begin{tabular}{|c|c|}
\hline İnsan Kaynakları Yönetimi Faktörleri & İlgili Çalışmalar \\
\hline İnsan Kaynakları Planlaması & $\begin{array}{l}\text { Kaynak, 1996; Partlow, 1996; Can vd., 1998; Özdemir ve } \\
\text { Akpınar , 2002; Akoğlan Kozak, 2004; Barutçugil, 2004; } \\
\text { Zhang ve Wu, 2004; Demir ve Güzel, 2005; Mirze, 2010; } \\
\text { Çam, 2011. }\end{array}$ \\
\hline İş Değerleme & $\begin{array}{l}\text { Tayfun, 1996; Ataay, 2004; Yenipınar, 2005; Keser, 2006; } \\
\text { Kurgun ve Alimanoğlu Yemişçi, 2007; Uyargil vd., 2008; } \\
\text { Dolgun, 2010. }\end{array}$ \\
\hline Performans Değerleme & $\begin{array}{l}\text { Turhan, 2001; Benligiray, 2006; Karakuş ve K1lınç, 2006; } \\
\text { Babalık, 2007; Arslantürk, 2009; Dessler 2009; Luecke, } 2010 .\end{array}$ \\
\hline Kariyer Yönetimi & $\begin{array}{l}\text { Akyay, 1998; Uygur, 1998; Ng ve Pine, 2003; Akoğlan } \\
\text { Kozak, 2004; Kuşluvan ve Kuşuvan, 2005; Kılıç ve Öztürk, } \\
\text { 2009; Türkay ve Eryılmaz, 2013. }\end{array}$ \\
\hline$\ddot{\text { Ücret Yönetimi }}$ & $\begin{array}{l}\text { Leka ve Cox, 2008; Emir ve Baytok, 2004; Kuşluvan ve } \\
\text { Kuşluvan, 2005; İnce, 2008; Tuncer ve Yeşiltaş, } 2013 .\end{array}$ \\
\hline İş Güvenliği & Bilgin, 1994; Çiçek ve Akoğlan Kozak, 2005; Dolgun, 2010. \\
\hline Çalışan Ílişkileri & $\begin{array}{l}\text { Brymer vd., 1991; Bilgin, 1994; Zohar, 1994; Edworthy, } \\
\text { 2000; Güney, 2001; Akoğlan Kozak, 2001; Şimşek vd., 2003; } \\
\text { Solmuş, 2004; Akçadağ ve Özdemir, 2005; Keser, 2006; } \\
\text { Akova ve Işık, 2008; Altay, 2009; Bolat; 2011; Toker, 2011; } \\
\text { Uzun ve Yiğit, 2011; Saldamlı, 2013. }\end{array}$ \\
\hline
\end{tabular}

$\mathrm{Bu}$ çalışmalardan elde edilen bilgilere bağlı olarak ve uzman görüşlerine başvurularak anket soru formu ifadeleri olușturulmuştur. Anket soru formu iki bölüm olarak düzenlemiştir. Birinci bölümde otel çalışanları ve yöneticilerinin, iş yükü ile ilgili algılamalarını belirlemeye yönelik 27 ifade; ikinci bölümde ise yöneticilerin insan kaynakları yönetim fonksiyonlarında iş yükünü dikkate almalarıyla ilgili 45 ifade yer almaktadır. Soru formunda ayrıca, çalışan ve yöneticilerin genel iş yükü algılamaları ile ilgili bir soru ve sekiz demografik soru da bulunmaktadır. Anket soru formunun birinci ve ikinci bölümünde yer alan ifadelerde 5’li Likert ölçeği (1: Kesinlikle katılmıyorum - 5: Kesinlikle katılıyorum) kullanılmıştır.
Araştırmanın yüzey ve kapsam geçerliliğini sağlamak amacıyla yönetim alanında uzman 5 akademisyenden bilgi alınmış ve soru formundaki ifadelerin istenilen boyutları ölçüp ölçmediğine karar verilerek ifadeler üzerinde düzeltmeler yapılmıştır. Daha sonra, otel çalışanları $(n=25)$ ve uzman kişilerden oluşan $(n=5)$ 30 kişi ile 18 Mart 2014 ve 30 Mayıs 2014 tarihleri arasında ikişer haftalık aralıklarla üç kez pilot çalışma tekrarlanmıştır. Bu kapsamda Cronbach Alpha güvenilirlik katsayılarına bakılmış ve faktör analizleri gerçekleştirilmiştir. Birinci ve ikinci pilot çalışma sonucunda, toplam korelasyon katsayıs 0,1 'in altında kalan ve faktör yükleri 0,3 'ün altında kalan ve iki faktör altında ele alınabilen ifadeler uzman görüşleri 
doğrultusunda yeniden düzenlenmiş ve iş yükünü belirlemeye yönelik 1 ifade ile insan kaynakları yönetimi fonksiyonlarına ilişkin 7 ifade, ölçeğin geçerliliğine uygun olmadığından çıkartılmıştır. 3. Pilot çalışma sonucunda iş yükü faktörlerine ilişkin Cronbach Alpha Değeri ,853 olarak; insan kaynakları yönetimi fonksiyonlarına ilişkin Cronbach Alpha Değeri ise ,892 olarak hesaplanmıştır. Uzman görüşleri ve pilot çalışmalar sonucunda araştırmaya otel çalışanlarının iş yükü algısıyla ilgili 26 ifade ve yöneticilerin insan kaynakları fonksiyonları bağlamında iş yükü algısına yönelik 38 ifadeyle başlanmıştır.

Çalışma 23 Haziran 2014 ve 16 Eylül 2014 tarihleri arasında üç aşamalı olarak gerçekleştirilmiştir. Verilerin elde edilmesinde ise yüz yüze anket tekniği uygulanmıştır. Elde edilen verilerin analizine başlamadan önce ters kodlanan sorular düzeltilmiş, eksik veri olan anketler kapsam dışı bırakılmış ve daha sonra dağılımın normalliğine bakılmıştır. Ortalamaların birbirine yakın olması, çarpıklık değerlerinin ve Kolmgorov Smirnov test sonuçlarının anlamlı düzeyde olması $(p>0,05)$ sonucunda dağılımın normal olduğuna karar verilmiştir.

\section{Bulguların Analizi}

Çalışmada ilk olarak çalışan ve yöneticilerin iş yükü algısına etki eden unsurları belirlemeye yönelik olarak faktör analizi gerçekleştirilmiştir. Dağılımın normalliğine, Kaiser-Meyer-Olkin değerlerine ve $(0,798)$ Bartlett Küresellik Testi $(2870,119)$ sonuçlarının anlamlılığına bakılarak $(\mathrm{p}<, 000)$ faktör analizinin uygunluğuna karar verilmiştir. Ayrıca, çapraz ilişki matrisi (anti-image correlation matrice) incelenerek bireysel örneklem uygunluk değeri (MSA) kontrol edilmiş, büyüklüğü 0,50 altında olan değere rastlanmamıştır. Verilerin faktör analizine uygun olduğuna karar verildikten sonra analiz uygulanmıştır. Faktör yük değeri ,30'un altında kalan (Büyüköztürk, 2002:118) faktörler olmadığından dolayı maddeler çıkartılmadan analiz gerçekleştirilmiştir. Faktör analizinin gerçekleștirilmesinde, temel bileşenler yöntemi kullanılmıştır. Ayrıca, faktör analizinin uygulanmasinda dik döndürme yöntemlerinden olan Equamax yöntemi tercih edilmiştir. Dik döndürme yöntemle- rinin birleşiminden oluşan Exuamax döndürme yönteminde, faktör yükleri 90 derece döndürülerek yük değerlerinin 1'e yaklaşmaları sağlanmakta, böylece faktör yüklerini açıklamak basitleşmektedir (Çokluk vd., 2014: 203). Faktör analizinin son aşaması olan faktörlerin adlandırılması ise gruplanan değişkenlerin bütün olarak ifade ettikleri anlamlar ve literatürdeki kullanım dikkate alınarak yapılmıştır. Tablo 3’te görüldüğü üzere çalışan ve yöneticilerin iş yükü alg1sını açıklayan beş faktörlü bir yapı ortaya çıkmıştır.

Tablo 3 incelendiğinde toplam varyansın \%12,20'si 'Konumsal Faktör' olarak adlandırılan birinci faktör, \%10,39'u 'Zihinsel Faktör' olarak adlandırılan ikinci faktör, \%10,17'si 'Çevresel Faktör' olarak adlandırılan üçüncü faktör, \%9,40’ 'Duygusal Çaba Faktörü’ olarak adlandırılan dördüncü faktör ve \%8,60' 'Fiziksel Faktör' olarak adlandırılan beşinci faktör tarafından açıklanmıştır.

Çalışmada, elde edilen iş yükü faktörleri ile çalışanların demografik özellikleri arası farklılıklar, bağımsız örneklem T Testi ile incelenmiştir. Tablo 4'te gösterilen analiz sonucunda, kadın çalışanların erkek çalışanlara oranla daha fazla çevresel iş yükü algıladıkları belirlenmiştir ( $p>0,05)$. Bu sonucun, çalışan kadınların fizyolojik anlamda fiziki kapasite ve dayanıklılık bakımından erkeklere nazaran daha güçsüz olmaları sonucu (Yılmaz, 2010) çevresel faktörlere yönelik olumsuzlukları erkeklere oranla daha yoğun algıladıkları ile ilişkili olabileceği düşünülmektedir. Medeni durum ile ilgili sonuçlara bakıldığında evli çalışanların duygusal, konumsal ve çevresel olarak daha fazla iş yükü algıladıkları görülmektedir. Elde edilen bu bulgu, turizm sektörünün iş-aile çatışmasına neden olan bir sektör olarak değerlendirildiği (Uzun ve Yiğit, 2011) görüşü ile örtüşmektedir. Diğer bir bulgu olarak, turizm eğitimi almış çalışanların zihinsel iş yükünü daha fazla algıladıkları sonucuna ulaşılmıştır. $\mathrm{Bu}$ durumun literatürde de değinilen (Özdemir vd., 2005) turizm eğitimi almış çalışanların turizm sektöründe çalışmayı stresli bulduklarından kaynaklandığı düşünülmektedir.

Çalışanların departman, eğitim durumu, yaş ve iş tecrübeleri ile iş yükü faktörlerine ilişkin algılama- 
Tablo 3. İ̧ Yükü Faktör Analizi Sonuçları

\begin{tabular}{|c|c|c|c|c|c|}
\hline Faktör ve İfadeler & Faktì & ükleri & Ort. & & Özdeğer \\
\hline $\begin{array}{l}\text { Konumsal Faktörler } \\
\text { 24.İşim gereği malzemelere sık sık itme ve çekme işlemleri } \\
\text { uygularım. } \\
\text { 23.Sürekli olarak ağır malzemeleri kaldırmam gerekiyor. } \\
\text { 22.İşimi çoğu zaman ayakta yapıyorum. } \\
\text { 25.Tezgah, desk, masa ve yatak gibi bazı malzemelerle çalışırken } \\
\text { zorlanırım. } \\
\text { 26.İş yaparken vücudumun bazı kısımlarında sık sık ağrılar oluyor. }\end{array}$ & $\begin{array}{l}, 790 \\
, 770 \\
, 621 \\
, 538 \\
, 505\end{array}$ & & $\begin{array}{l}2,92 \\
2,69 \\
3,97 \\
2,64 \\
3,30\end{array}$ & $12,20 \%$ & 3,174 \\
\hline $\begin{array}{l}\text { Zihinsel Faktörler } \\
\text { 12.İşim gereği birçok şeyi hatırlamam şart. } \\
\text { 10.Yaptığım iş sürekli dikkat gerektiriyor. } \\
\text { 14.İşimi yaparken iş arkadaşlarımla sürekli iletişim kurmam } \\
\text { gerekiyor. } \\
\text { 15.Iş̧imi müşterilerle aynı ortamda yapmak ve hata yapma korkusu } \\
\text { beni geriyor. } \\
\text { 11.Çoğu zaman doğru karar vermek için araştırma yapmam gerekiyor. } \\
\text { 16.İş yaparken konsantre olmama gerek yok. }\end{array}$ & & $\begin{array}{l}, 799 \\
, 744 \\
, 691 \\
, 532 \\
, 445 \\
, 373\end{array}$ & $\begin{array}{l}4,16 \\
4,09 \\
4,18 \\
4,14 \\
3,45 \\
2,28\end{array}$ & $10,39 \%$ & 2,703 \\
\hline $\begin{array}{l}\text { Çevresel Faktörler } \\
\text { 19.Çalıştığım ortamdaki makine vb. aletlerin titreşimi beni rahatsız } \\
\text { ediyor. } \\
\text { 18.Çalışma alanımdaki gürültü, çoğu zaman işimi engelliyor. } \\
\text { 21.İş yerindeki nemli ortamdan dolayı rahatsızlık duyuyorum. } \\
\text { 20.Çalıştığım ortamın ısısı çoğu zaman beni rahatsız ediyor. } \\
\text { 17.İş yapmam için iyi bir ışılandırma son derece önemli. }\end{array}$ & $\begin{array}{l}, 801 \\
, 740 \\
, 646 \\
, 608 \\
, 502\end{array}$ & & $\begin{array}{l}2,45 \\
2,58 \\
2,60 \\
3,05 \\
3,53\end{array}$ & $10,17 \%$ & 2,645 \\
\hline $\begin{array}{l}\text { Duygusal Çaba Faktörleri } \\
\text { 3.İşimi yaparken rol yapmak zorunda kalıyorum. } \\
\text { 1.İşimi yaparken, 'kan kusup kızılcık şerbeti içtim' diyorum. } \\
\text { 2.Müşterinin sıkıntılarını dinlemek beni üzüyor. } \\
\text { 13.Yaptığım iş beni strese sokuyor ve tüketiyor. } \\
\text { 4.İşyerinde duyguların nasıl sergilenmesi gerektiğini belirten } \\
\text { (gülümseme, kibar olma vb.) kurallara uyarım }\end{array}$ & & $\begin{array}{l}, 673 \\
, 672 \\
, 557 \\
, 549 \\
481\end{array}$ & $\begin{array}{l}2,54 \\
2,24 \\
2,56 \\
3,09 \\
3,19\end{array}$ & $9,40 \%$ & 2,445 \\
\hline $\begin{array}{l}\text { Fiziksel Faktörler } \\
\text { 6.İşimden dolayı çok fazla hareket etmem gerekiyor. } \\
\text { 5.Yaptığım iş çoğunlukla fiziksel çaba gerektirir. } \\
\text { 7.Çalışma sürelerim diğer departmanlardaki iş sürelerine göre daha } \\
\text { fazladır. } \\
\text { 9.Yaptığım işin fiziksel zorluğundan dolayı çok yoruluyorum. } \\
\text { 8.Molalarımızın yeterli olmadığını düşünüyorum. }\end{array}$ & $\begin{array}{l}, 695 \\
, 685 \\
, 642 \\
, 460 \\
, 383\end{array}$ & & $\begin{array}{l}3,58 \\
3,57 \\
2,97 \\
\\
3,13 \\
2,75\end{array}$ & $8,60 \%$ & 2,238 \\
\hline $\begin{array}{l}\text { Açıklanan Varyans } \\
\text { Cronbach's Alpha Güvenilirlik Katsayısı ( } \alpha)\end{array}$ & & & & $\begin{array}{l}50,78 \% \\
, 798\end{array}$ & \\
\hline
\end{tabular}

ları arası farklıllklar ise tek yönlü varyans analizi (ANOVA) ile ölçülmüştür. Varyansların eşit dağılımı varsayımı sağlandığı durumlarda LSD, varsyansların eşit dağılımı varsayımının sağlanmadığı durumlarda ise Tamhane's 2 testinin sonuçları değerlendirilmeye alınmıştır. LSD testi, dik karşılaştırmalar olarak da bilinen ve her ortalamanın yalnızca bir kez kullanıldığ karşılaştırmalarda daha uygun olan, gruplar aras1 kombinasyonları verilen cevapların ortalamalarını alarak hesaplayan bir yöntemdir (Alpar, 2014, s. 260). 
Tablo 4. Iş̧ Yükü Faktörlerinin Çalışanların Cinsiyet, Medeni Durum ve Turizm Eğitimi Alma Durumlarına Göre Değişimi

\begin{tabular}{|c|c|c|c|c|c|c|c|c|c|}
\hline Faktör & Cinsiyet & Ort. & P Değ. & $\begin{array}{l}\text { Medeni } \\
\text { Durum }\end{array}$ & Ort. & $\begin{array}{l}\mathbf{P} \\
\text { Değ. }\end{array}$ & $\begin{array}{l}\text { Turizm } \\
\text { Eğitimi }\end{array}$ & Ort. & $\begin{array}{l}\mathbf{P} \\
\text { Değ }\end{array}$ \\
\hline Duygusal Çaba Fkt. & $\begin{array}{l}\text { Kadın } \\
\text { Erkek }\end{array}$ & $\begin{array}{l}2,66 \\
2,57\end{array}$ &, $380 * *$ & $\begin{array}{l}\text { Bekar } \\
\text { Evli }\end{array}$ & $\begin{array}{l}2,55 \\
2,74\end{array}$ &, $040 * *$ & $\begin{array}{l}\text { Almış } \\
\text { Almamış }\end{array}$ & $\begin{array}{l}2,62 \\
2,61\end{array}$ & ,915* \\
\hline Fiziksel Fkt. & $\begin{array}{l}\text { Kadın } \\
\text { Erkek }\end{array}$ & $\begin{array}{l}3,29 \\
2,19\end{array}$ & ,402* & $\begin{array}{l}\text { Bekar } \\
\text { Evli }\end{array}$ & $\begin{array}{l}3,19 \\
3,35\end{array}$ &, $182 *$ & $\begin{array}{l}\text { Almış } \\
\text { Almamış }\end{array}$ & $\begin{array}{l}3,20 \\
3,27\end{array}$ &, $526^{*}$ \\
\hline Zihinsel Fkt. & $\begin{array}{l}\text { Kadın } \\
\text { Erkek }\end{array}$ & $\begin{array}{l}3,87 \\
3,94\end{array}$ & ,411* & $\begin{array}{l}\text { Bekar } \\
\text { Evli }\end{array}$ & $\begin{array}{l}3,95 \\
3,82\end{array}$ &, $152 *$ & $\begin{array}{l}\text { Almış } \\
\text { Almamış }\end{array}$ & $\begin{array}{l}4,08 \\
3,80\end{array}$ & ,001* \\
\hline Konumsal Fkt. & $\begin{array}{l}\text { Kadın } \\
\text { Erkek }\end{array}$ & $\begin{array}{l}3,22 \\
3,25\end{array}$ & ,803* & $\begin{array}{l}\text { Bekar } \\
\text { Evli }\end{array}$ & $\begin{array}{l}3,14 \\
3,42\end{array}$ &, $020^{*}$ & $\begin{array}{l}\text { Almış } \\
\text { Almamış }\end{array}$ & $\begin{array}{l}3,10 \\
3,32\end{array}$ & ,057* \\
\hline Çevresel Fkt. & $\begin{array}{l}\text { Kadın } \\
\text { Erkek }\end{array}$ & $\begin{array}{l}2,98 \\
2,72\end{array}$ &, $020^{*}$ & $\begin{array}{l}\text { Bekar } \\
\text { Evli }\end{array}$ & $\begin{array}{l}2,73 \\
3,10\end{array}$ &, $002^{*}$ & $\begin{array}{l}\text { Almış } \\
\text { Almamış }\end{array}$ & $\begin{array}{l}2,80 \\
2,89\end{array}$ & $4,466^{*}$ \\
\hline
\end{tabular}

*Varyanslar eşit dağıllmadığında ortaya çıkan $p$ değeri temel alınarak değerlendirme yapılımıştır.

**Varyanslar eşit dağıldığında ortaya çıkan p değeri temel alınarak değerlendirme yapılııștır.

Tablo 5. Iş̧ Yükü Faktörlerinin Çalışanların Departmanlarına ve Eğitim Durumlarına Göre Değişimi

\begin{tabular}{|c|c|c|c|c|c|c|c|c|}
\hline & \multicolumn{4}{|c|}{ Departman } & \multicolumn{4}{|c|}{ Eğitim Durumu } \\
\hline & & Ort. & P Değ. & Fark & & Ort. & P Değ. & Fark \\
\hline $\begin{array}{l}\text { Duygusal Çaba } \\
\text { Fkt. }\end{array}$ & $\begin{array}{l}\text { Ön Büro (a) } \\
\text { Yiyecek-İçecek (b) } \\
\text { Kat Hizmetleri (c) } \\
\text { Diğer Departmanlar (d) }\end{array}$ & $\begin{array}{l}2,56 \\
2,60 \\
2,77 \\
1,85\end{array}$ &, $072 * *$ & - & $\begin{array}{l}\text { İlköğretim (a) } \\
\text { Lise (b) } \\
\text { Ön Lisans (c) } \\
\text { Lisans (d) } \\
\text { Lisans Üstü (e) }\end{array}$ & $\begin{array}{l}2,73 \\
2,65 \\
2,86 \\
2,42 \\
2,73\end{array}$ & ,036* & $\begin{array}{l}a>d \\
b>d \\
c>d\end{array}$ \\
\hline Fiziksel Fkt. & $\begin{array}{l}\text { Ön Büro (a) } \\
\text { Yiyecek-İçecek (b) } \\
\text { Kat Hizmetleri (c) } \\
\text { Diğer Departmanlar (d) }\end{array}$ & $\begin{array}{l}2,80 \\
3,49 \\
3,49 \\
2,70\end{array}$ &, $001 *$ & $\begin{array}{l}b>a \\
c>a\end{array}$ & $\begin{array}{l}\text { İlköğretim (a) } \\
\text { Lise (b) } \\
\text { Ön Lisans (c) } \\
\text { Lisans (d) } \\
\text { Lisans Üstü (e) }\end{array}$ & $\begin{array}{l}3,58 \\
3,40 \\
3,13 \\
2,91 \\
3,06\end{array}$ &, $001 *$ & $\begin{array}{l}a>c \\
a>d \\
b>d\end{array}$ \\
\hline Zihinsel Fkt. & $\begin{array}{l}\text { Ön Büro (a) } \\
\text { Yiyecek-İçecek (b) } \\
\text { Kat Hizmetleri (c) } \\
\text { Diğer Departmanlar (d) }\end{array}$ & $\begin{array}{l}4,07 \\
3,85 \\
3,76 \\
4,33\end{array}$ &, $019^{*}$ & $\begin{array}{l}a>b \\
a>c\end{array}$ & $\begin{array}{l}\text { İlköğretim (a) } \\
\text { Lise (b) } \\
\text { Ön Lisans (c) } \\
\text { Lisans (d) } \\
\text { Lisans Üstü (e) }\end{array}$ & $\begin{array}{l}3,54 \\
3,88 \\
4,17 \\
4,07 \\
4,22\end{array}$ &, $001^{*}$ & $\begin{array}{l}\text { d }>a \\
c>a \\
c>b\end{array}$ \\
\hline Konumsal Fkt. & $\begin{array}{l}\text { Ön Büro (a) } \\
\text { Yiyecek-İçecek (b) } \\
\text { Kat Hizmetleri (c) } \\
\text { Diğer Departmanlar (d) }\end{array}$ & $\begin{array}{l}2,95 \\
3,32 \\
3,56 \\
2,35\end{array}$ &, $001^{*}$ & $\begin{array}{l}b>a \\
b>d \\
c>a \\
c>d\end{array}$ & $\begin{array}{l}\text { İlköğretim (a) } \\
\text { Lise (b) } \\
\text { Ön Lisans (c) } \\
\text { Lisans (d) } \\
\text { Lisans Üstü (e) }\end{array}$ & $\begin{array}{l}3,62 \\
3,33 \\
3,11 \\
2,93 \\
3,46\end{array}$ &, $001 *$ & $\begin{array}{l}a>c \\
a>d \\
b>d\end{array}$ \\
\hline Çevresel Fkt. & $\begin{array}{l}\text { Ön Büro (a) } \\
\text { Yiyecek-İçecek (b) } \\
\text { Kat Hizmetleri (c) } \\
\text { Diğer Departmanlar (d) }\end{array}$ & $\begin{array}{l}2,66 \\
2,85 \\
3,16 \\
2,30\end{array}$ &, $005^{*}$ & $c>a$ & $\begin{array}{l}\text { İlköğretim (a) } \\
\text { Lise (b) } \\
\text { Ön Lisans (c) } \\
\text { Lisans (d) } \\
\text { Lisans Üstü (e) }\end{array}$ & $\begin{array}{l}3,27 \\
2,67 \\
2,84 \\
2,81 \\
2,26\end{array}$ &, $002 *$ & $\begin{array}{l}a>b \\
a>c \\
a>d\end{array}$ \\
\hline
\end{tabular}

** Varyansların eşitliği varsayımı sağlanmamıştır.

Çalışanların departmanları ile iş yükü faktörleri arası ilişkiye bakıldığında (Tablo 5) yiyecek içecek ve kat hizmetleri departmanlarının ön büro ve diğer departmanlara oranla daha fazla konumsal iş yükü algıladıkları belirlenmiştir. Yiyecek içecek ve kat hizmetleri departmanlarında çalışanların, işle ilgili olarak malzemeleri taşıma, itme-çekme ve vücudu sürekli eğme-döndürme gibi faaliyetlerin yerine ge- 
tirilmesi, bu departmanlarda çalışanlar açısından konumsal anlamda iş yükünü diğer departmanalara oranla artırmaktadır. Fiziksel faktörler bakımından, yiyecek içecek ve kat hizmetleri departmanlarının ön büro departmanından; zihinsel faktörler bakımından ise tam tersine ön büro departmanının kat hizmetleri ve yiyecek içecek departmanlarından daha fazla iş yükü algıladıkları belirlenmiştir. Bilindiği gibi ön büro çalışanları rezervasyon alma, müşteri giriş ve ç1kışlarını yapma gibi daha fazla zihinsel çaba gerektiren işleri yerine getirirken; kat hizmetleri departmanı çalışanları temizlik gibi ve yiyecek-içecek departmanı çalışanları servis yapma, yemek hazırlama gibi daha fazla fiziksel çaba gerektiren işleri yerine getirmektedir. Bu nedenle, ön büro departmanında zihinsel iş yükü algısı fazlayken, kat hizmetleri ve yiyecek içecek departmanlarında fiziksel iş yükü algısı daha fazla algilanmaktadır.

Eğitim durumuna ilişkin farklılıklarda ise (Tablo 5) duygusal çaba bakımından ilköğretim, lise ve ön lisans mezunlarının lisans mezunlarından daha fazla iş yükü algıladıkları belirlenmiştir. Fiziksel faktörler bakımından, ilköğretim mezunlarının lise; ayrıca lise mezunlarının da lisans mezunlarından daha fazla iş yükü ağıladıkları görülmektedir. Konumsal faktörler

Tablo 6. İ̧̧ Yükü Faktörlerinin Çalışanların Yaşlarına ve Iş̧ Tecrübelerine Göre Değişimi

\begin{tabular}{|c|c|c|c|c|c|c|c|c|}
\hline & \multicolumn{4}{|c|}{ Yaş } & \multicolumn{4}{|c|}{ İş Tecrübesi } \\
\hline & & Ort. & P Değ. & Fark & & Ort. & P Değ. & Fark \\
\hline $\begin{array}{l}\text { Duygusal } \\
\text { Çaba Fkt. }\end{array}$ & $\begin{array}{l}15-20 \text { yaş (a) } \\
21-26 \text { yaş (b) } \\
27-32 \text { yas (c) } \\
33-38 \text { yaş (d) } \\
39-44 \text { yas (e) } \\
45-50 \text { yaş (f) } \\
51 \text { yaş ve üzeri }(\mathrm{g})\end{array}$ & $\begin{array}{l}2,41 \\
2,57 \\
2,73 \\
2,64 \\
2,71 \\
2,90 \\
2,46\end{array}$ &, $417 * *$ & - & $\begin{array}{l}1-4 \text { y1l (a) } \\
5-9 \text { y1l (b) } \\
10-14 \text { y1l (c) } \\
15-19 \text { y1l (d) } \\
20 \text { yıl ve üzeri } \\
\text { (e) }\end{array}$ & $\begin{array}{l}2,57 \\
2,65 \\
2,68 \\
2,82 \\
3,60\end{array}$ & ,022* & $\begin{array}{l}\text { e }>a \\
\text { e }>\text { b }\end{array}$ \\
\hline Fiziksel Fkt. & $\begin{array}{l}15-20 \text { yaş (a) } \\
21-26 \text { yaş (b) } \\
27-32 \text { yaş (c) } \\
33-38 \text { yaş (d) } \\
39-44 \text { yaş (e) } \\
45-50 \text { yaş (f) } \\
51 \text { yaş ve üzeri }(\mathrm{g})\end{array}$ & $\begin{array}{l}3,43 \\
3,11 \\
3,23 \\
3,32 \\
3,43 \\
3,35 \\
3,73\end{array}$ &, $001^{* *}$ & $\begin{array}{l}g>b \\
g>c\end{array}$ & $\begin{array}{l}1-4 \text { yıl (a) } \\
5-9 \text { y1l (b) } \\
10-14 \text { yil (c) } \\
15-19 \text { y1l (d) } \\
20 \text { yıl ve üzeri } \\
\text { (e) }\end{array}$ & $\begin{array}{l}3,25 \\
3,11 \\
3,63 \\
3,35 \\
3,20\end{array}$ & ,046* & $c>b$ \\
\hline Zihinsel Fkt. & $\begin{array}{l}15-20 \text { yaş (a) } \\
21-26 \text { yaş (b) } \\
27-32 \text { yaş (c) } \\
33-38 \text { yaş (d) } \\
39-44 \text { yaş (e) } \\
45-50 \text { yaş (f) } \\
51 \text { yaş ve üzeri }(\mathrm{g})\end{array}$ & $\begin{array}{l}3,85 \\
4,01 \\
4,00 \\
3,76 \\
3,67 \\
3,45 \\
3,66\end{array}$ & ,044* & $\begin{array}{l}b>e \\
b>f \\
c>f\end{array}$ & $\begin{array}{l}1-4 \text { y1l (a) } \\
5-9 \text { y1l (b) } \\
10-14 \text { y1l (c) } \\
15-19 \text { y1l (d) } \\
20 \text { y1l ve üzeri } \\
\text { (e) }\end{array}$ & $\begin{array}{l}3,90 \\
3,99 \\
3,80 \\
3,77 \\
3,33\end{array}$ &, $451^{* *}$ & - \\
\hline $\begin{array}{l}\text { Konumsal } \\
\text { Fkt. }\end{array}$ & $\begin{array}{l}15-20 \text { yaş (a) } \\
21-26 \text { yaş (b) } \\
27-32 \text { yas (c) } \\
33-38 \text { yaş (d) } \\
39-44 \text { yaş (e) } \\
45-50 \text { yaş (f) } \\
51 \text { yaş ve üzeri }(\mathrm{g})\end{array}$ & $\begin{array}{l}3,58 \\
3,02 \\
3,31 \\
3,22 \\
3,57 \\
3,26 \\
3,73\end{array}$ & ,020* & $\begin{array}{l}a>b \\
c>b \\
e>b\end{array}$ & $\begin{array}{l}\text { 1-4 y1l (a) } \\
5-9 \text { y1l (b) } \\
10-14 \text { y1l (c) } \\
15-19 \text { y1l (d) } \\
20 \text { y1l ve üzeri } \\
\text { (e) }\end{array}$ & $\begin{array}{l}3,26 \\
3,13 \\
3,38 \\
3,45 \\
2,66\end{array}$ &, $563^{* *}$ & - \\
\hline Çevresel Fkt. & $\begin{array}{l}15-20 \text { yaş (a) } \\
21-26 \text { yaş (b) } \\
27-32 \text { yaş (c) } \\
33-38 \text { yaş (d) } \\
39-44 \text { yaş (e) } \\
45-50 \text { yaş (f) } \\
51 \text { yaş ve üzeri }(\mathrm{g})\end{array}$ & $\begin{array}{l}2,57 \\
2,78 \\
3,00 \\
2,92 \\
3,20 \\
2,88 \\
2,66\end{array}$ & ,048* & $\begin{array}{l}c>a \\
e>a \\
e>b\end{array}$ & $\begin{array}{l}1-4 \text { yil (a) } \\
5-9 \text { y1l (b) } \\
10-14 \text { yil (c) } \\
15-19 \text { y1l (d) } \\
20 \text { yıl ve üzeri } \\
\text { (e) }\end{array}$ & $\begin{array}{l}2,84 \\
2,93 \\
2,75 \\
2,85 \\
2,86\end{array}$ & ,942** & - \\
\hline
\end{tabular}

* Varyansların eșitliği varsayımı sağlanmıştır.

** Varyansların eşitliği varsayımı sağlanmamıștır. 
bakımından ise ilköğretim mezunlarının lise ve ön lisans mezunlarından; ön lisans mezunlarının ise lisans mezunlarından daha fazla iş yükü algıladıkları ortaya çıkmıştır. Son olarak, çevresel faktörler bakımından, ilköğretim mezunlarının lise, ön lisans ve lisans mezunlarından daha fazla iş yükü algıladıkları görülmektedir. Bu dört faktör bakımından değerlendirilecek olursa, en fazla iş yükü algısını ilköğretim mezunlarının hissettiği ve çalışanların eğitim durumları arttıkça bu faktörler bağlamında algıladıkları iş yükünün azalabileceği söylenebilir. Bulgularda zihinsel faktörler bakımından ise bu durumun tersi gözlemlenmektedir. Lisans mezunlarının ilköğretim ve lise mezunlarından; ön lisans mezunlarının ise ilköğretim mezunlarından daha fazla zihinsel iş yükü algıladıkları belirlenmiştir. Zihinsel iş yükünün en fazla algılandığ 1 departmanın ön büro departmanı olması ve en fazla lisans mezunu çalışanın ön büro departmanında çalışması $(\mathrm{n}=48)$ bu durumu açıklamaktadır.

Çalışanların yaşları ve iş yükleri arasındaki farklıliklar incelendiğinde (Tablo 6), fiziksel faktörler bakımından 51 yaş ve üzeri çalışanların, 21-26 yaş ve 27-32 yaşındaki çalışanlara oranla daha fazla iş yükü algıladıkları belirlenmiştir. Yani yaş arttıkça fiziksel iş yükü algısı da artabilmektedir. Zihinsel faktörler bakımından ise 21-26 yaş grubundaki çalışanların, 39-44 yaş ve 45-50 yaş grubundaki çalışanlara oranla daha fazla iş yükü algıladıkları görülmektedir. 21-26 yaş grubunun en fazla ön büro departmanında çalı̧̧ması $(n=55)$ ve bu departmanda zihinsel iş yükünün fazla olması bu sonucu desteklemektedir. Konumsal iş yükü algısı bakımından 15-20 yaş, 27-32 yaş ve 3944 yaş grubunun 21-26 yaş grubuna oranla daha fazla iş yükü algıladıkları belirlenmiştir. Bu bağlamda, çalışanların çok genç veya çok yaşlı olmalarının iş yükü algılarını arttırdığı söylenebilir. Son olarak çevresel faktörler bakımından ise 27-32 yaş ve 39-44 yaş grubunun 15-20 yaş grubundan; 39-44 yaş grubunun ise
21-26 yas grubundan daha fazla iş yükü algıladıkları belirlenmiştir. Çevresel faktörlerde ise konumsal faktörlerden farklı olarak yaş arttıkça iş yükü algısının da $\operatorname{arttığı~sonucu~ortaya~çıkmaktadır.~}$

Çalışanların iş tecrübeleri ve iş yükü algıları arasındaki ilişkiye bakıldığında (Tablo 6) duygusal çaba bakımından, 20 yıl ve üzeri iş tecrübesi olanların, 1-4 yıl 5-9 yll iş tecrübesi olan çalışanlara oranla daha fazla iş yükü algıladıkları belirlenmiştir. Bu nedenle, çalışanların iş tecrübesi arttıkça işe ve müşterilere uyum sürecinde zorlandıkları ve duygusal çabalarının arttığı söylenebilir. Fiziksel faktörler bakımından ise 10-14 yıl arası iş tecrübesi olan çalışanların 5-9 yıl arası iş tecrübesi olan çalışanlardan fazla iş yükü algıladıkları görülmüștür. İş tecrübesinin en fazla 1-4 yil grubunda ( $n=173)$ bulunması, Eskişehir'de otel çalışanlarının bu sektörde daha yeni olduklarını göstermektedir. İş yükü algısı, yaş farklılıklarında da görüldüğü gibi zamanla artma eğilimi olan bir alg1 olduğundan, iş tecrübesi az olan çalışanların bulunduğu grupta zihinsel faktörler, konumsal faktörler ve çevresel faktörler açısından algının az olması anlamlı bir farklılığı engellemektedir.

Tablo 7'deki yöneticilere ilişkin bulgular değerlendirildiğinde cinsiyet, medeni durum ve turizm eğitimi bakımından anlamlı farklılıklar olmadığı saptanmıştır. Cinsiyet bakımından ortalamalarda görülen bu benzerlik, cinsiyet temelinde iş yükü algısında bir farklılık olmamasına, yani kadın ve erkek yöneticilerin işlerini aynı düzeyde ağır olarak algıladıklarına yorulabilir. Daha önce yapılan bir çalışmada da (Sökmen, 2005) cinsiyet etmeninin iş yükü kapsamında bir farklılık yaratamadığı saptanmıştır. Diğer yandan, turizm eğitimi ve medeni duruma bakıldığında, bekar ve evli yönetici oranları ile turizm eğitimi almış ve almamış yönetici oranlarının birbirine yakın olması durumunun, arada farklllıkların belirlenmesini önlediği görülmektedir. 
Tablo 7. İş Yükü Faktörlerinin Yöneticilerin Cinsiyet, Medeni Durum ve Turizm Eğitimi Alma Durumlarına Göre Değişimi

\begin{tabular}{|c|c|c|c|c|c|c|c|c|c|}
\hline Faktör & Cinsiyet & Ort. & P Değ. & $\begin{array}{l}\text { Medeni } \\
\text { Durum }\end{array}$ & Ort. & P Değ. & $\begin{array}{l}\text { Turizm } \\
\text { Eğitimi }\end{array}$ & Ort. & P Değ \\
\hline Duygusal Çaba Fkt. & $\begin{array}{l}\text { Kadın } \\
\text { Erkek }\end{array}$ & $\begin{array}{l}2,78 \\
2,85\end{array}$ & ,713* & $\begin{array}{l}\text { Bekar } \\
\text { Evli }\end{array}$ & $\begin{array}{l}2,70 \\
3,03\end{array}$ &, $051 * *$ & $\begin{array}{l}\text { Almış } \\
\text { Almamış }\end{array}$ & $\begin{array}{l}2,84 \\
2,80\end{array}$ & ,809* \\
\hline Fiziksel Fkt. & $\begin{array}{l}\text { Kadın } \\
\text { Erkek }\end{array}$ & $\begin{array}{l}2,94 \\
3,25\end{array}$ & ,086* & $\begin{array}{l}\text { Bekar } \\
\text { Evli }\end{array}$ & $\begin{array}{l}3,09 \\
3,18\end{array}$ & ,630* & $\begin{array}{l}\text { Almış } \\
\text { Almamış }\end{array}$ & $\begin{array}{l}3,18 \\
3,06\end{array}$ &, $510^{*}$ \\
\hline Zihinsel Fkt. & $\begin{array}{l}\text { Kadın } \\
\text { Erkek }\end{array}$ & $\begin{array}{l}4,07 \\
4,14\end{array}$ & ,635* & $\begin{array}{l}\text { Bekar } \\
\text { Evli }\end{array}$ & $\begin{array}{l}4,08 \\
4,17\end{array}$ & ,459* & $\begin{array}{l}\text { Almış } \\
\text { Almamıș }\end{array}$ & $\begin{array}{l}4,11 \\
4,11\end{array}$ & ,959* \\
\hline Konumsal Fkt. & $\begin{array}{l}\text { Kadın } \\
\text { Erkek }\end{array}$ & $\begin{array}{l}2,58 \\
2,89\end{array}$ &, $150^{*}$ & $\begin{array}{l}\text { Bekar } \\
\text { Evli }\end{array}$ & $\begin{array}{l}2,71 \\
2,85\end{array}$ & ,479* & $\begin{array}{l}\text { Almış } \\
\text { Almamış }\end{array}$ & $\begin{array}{l}2,71 \\
2,82\end{array}$ & ,606* \\
\hline Çevresel Fkt. & $\begin{array}{l}\text { Kadın } \\
\text { Erkek }\end{array}$ & $\begin{array}{l}2,80 \\
2,87\end{array}$ & ,697* & $\begin{array}{l}\text { Bekar } \\
\text { Evli }\end{array}$ & $\begin{array}{l}2,72 \\
3,03\end{array}$ &, $131^{*}$ & $\begin{array}{l}\text { Almış } \\
\text { Almamış }\end{array}$ & $\begin{array}{l}2,97 \\
2,69\end{array}$ &, $132^{* *}$ \\
\hline
\end{tabular}

*Varyanslar eşit dağılmadığında ortaya çıkan p değeri temel alınarak değerlendirme yapılmıştır.

**Varyanslar eşit dağıldığında ortaya çıkan p değeri temel alınarak değerlendirme yapılmıştır.

Tablo 8. İ̧̧ Yükü Faktörlerinin Yöneticilerin Departmanlarına ve Eğitim Durumlarına Göre Değişimi

\begin{tabular}{|c|c|c|c|c|c|c|c|c|}
\hline & \multicolumn{4}{|c|}{ Departman } & \multicolumn{4}{|c|}{ Eğitim Durumu } \\
\hline & & Ort. & P Değ. & Fark & & Ort. & P Değ. & Fark \\
\hline $\begin{array}{l}\text { Duygusal } \\
\text { Çaba Fkt. }\end{array}$ & $\begin{array}{l}\text { Genel Müdürler (a) } \\
\text { İnsan Kaynakları Md/Şefleri (b) } \\
\text { Ön Büro Md /Şefleri (c) } \\
\text { Yiyecek-İçecek Md /Şefleri (d) } \\
\text { Kat Hizmetleri Md /Şefleri (e) } \\
\text { Diğer Departman Md /Şefleri (f) }\end{array}$ & $\begin{array}{l}2,78 \\
2,92 \\
2,87 \\
2,78 \\
2,98 \\
2,30\end{array}$ & ,776* & - & $\begin{array}{l}\text { Ilköğretim } \\
\text { Lise } \\
\text { Ön Lisans } \\
\text { Lisans } \\
\text { Lisans Üstü }\end{array}$ & $\begin{array}{l}1,70 \\
3,07 \\
2,53 \\
2,83 \\
2,88\end{array}$ &, $046^{*}$ & $\begin{array}{l}\mathrm{b}>\mathrm{a} \\
\mathrm{d}>\mathrm{a}\end{array}$ \\
\hline $\begin{array}{l}\text { Fiziksel } \\
\text { Fkt. }\end{array}$ & $\begin{array}{l}\text { Genel Müdürler (a) } \\
\text { İnsan Kaynakları Md/Şefleri (b) } \\
\text { Ön Büro Md /Şefleri (c) } \\
\text { Yiyecek-İçecek Md /Şefleri (d) } \\
\text { Kat Hizmetleri Md /Şefleri (e) } \\
\text { Diğer Departman Md /Şefleri (f) }\end{array}$ & $\begin{array}{l}2,66 \\
2,94 \\
2,84 \\
3,61 \\
2,89 \\
3,30\end{array}$ & ,003* & $\begin{array}{l}\text { d>a } \\
d>b \\
d>c \\
d>e\end{array}$ & $\begin{array}{l}\text { İlköğretim } \\
\text { Lise } \\
\text { Ön Lisans } \\
\text { Lisans } \\
\text { Lisans Üstü }\end{array}$ & $\begin{array}{l}3,40 \\
3,38 \\
3,00 \\
3,04 \\
3,37\end{array}$ & $650^{*}$ & - \\
\hline $\begin{array}{l}\text { Zihinsel } \\
\text { Fkt. }\end{array}$ & $\begin{array}{l}\text { Genel Müdürler (a) } \\
\text { İnsan Kaynakları Md/Şefleri (b) } \\
\text { Ön Büro Md /Şefleri (c) } \\
\text { Yiyecek-İçecek Md /Şefleri (d) } \\
\text { Kat Hizmetleri Md /Şefleri (e) } \\
\text { Diğer Departman Md /Şefleri (f) }\end{array}$ & $\begin{array}{l}4,50 \\
4,13 \\
4,08 \\
3,95 \\
4,12 \\
4,25\end{array}$ &, $010^{*}$ & $\begin{array}{l}a>c \\
a>d\end{array}$ & $\begin{array}{l}\text { Ilköğretim } \\
\text { Lise } \\
\text { Ön Lisans } \\
\text { Lisans } \\
\text { Lisans Üstü }\end{array}$ & $\begin{array}{l}4,41 \\
4,00 \\
4,27 \\
4,17 \\
3,66\end{array}$ &, $020^{*}$ & $\mathrm{~d}>\mathrm{e}$ \\
\hline $\begin{array}{l}\text { Konumsal } \\
\text { Fkt. }\end{array}$ & $\begin{array}{l}\text { Genel Müdürler (a) } \\
\text { İnsan Kaynakları Md/Şefleri (b) } \\
\text { Ön Büro Md /Şefleri (c) } \\
\text { Yiyecek-İçecek Md /Şefleri (d) } \\
\text { Kat Hizmetleri Md /Şefleri (e) } \\
\text { Diğer Departman Md /Şefleri (f) }\end{array}$ & $\begin{array}{l}2,15 \\
2,38 \\
2,49 \\
3,28 \\
3,05 \\
2,30\end{array}$ &, $001^{*}$ & $\begin{array}{l}\text { d }>a \\
d>b \\
d>c \\
d>f \\
e>a\end{array}$ & $\begin{array}{l}\text { Illköğretim } \\
\text { Lise } \\
\text { Ön Lisans } \\
\text { Lisans } \\
\text { Lisans Üstü }\end{array}$ & $\begin{array}{l}3,20 \\
3,43 \\
2,90 \\
2,64 \\
2,57\end{array}$ &, $014 *$ & $b>d$ \\
\hline $\begin{array}{l}\text { Çevresel } \\
\text { Fkt. }\end{array}$ & $\begin{array}{l}\text { Genel Müdürler (a) } \\
\text { İnsan Kaynakları Md/Şefleri (b) } \\
\text { Ön Büro Md /Şefleri (c) } \\
\text { Yiyecek-İçecek Md /Şefleri (d) } \\
\text { Kat Hizmetleri Md /Şefleri (e) } \\
\text { Diğer Departman Md /Şefleri (f) }\end{array}$ & $\begin{array}{l}2,73 \\
2,87 \\
3,19 \\
2,78 \\
2,74 \\
2,05\end{array}$ & ,226* & - & $\begin{array}{l}\text { Ilköğretim } \\
\text { Lise } \\
\text { Ön Lisans } \\
\text { Lisans } \\
\text { Lisans Üstü }\end{array}$ & $\begin{array}{l}2,50 \\
3,01 \\
2,50 \\
2,87 \\
2,71\end{array}$ &, $758 * *$ & - \\
\hline
\end{tabular}

* Varyansların eşitliği varsayımı sağlanmıștır.

** Varyansların eşitliği varsayımı sağlanmamıștır. 
İş yükü faktörleri ile yöneticilerin departmanları arası ilişki Tablo 8'deki gibidir. Fiziksel faktörler bakımından yiyecek içecek departmanı yöneticilerinin genel müdürlere, insan kaynakları yöneticilerine, ön büro yöneticilerine ve kat hizmetleri yöneticilerine oranla daha fazla iş yükü algıladıkları belirlenmiştir. Yine yiyecek-içecek yöneticilerinin benzer şekilde konumsal faktörler bakımından genel müdürlere, insan kaynakları yöneticilerine, ön büro yöneticilerine ve diğer departman yöneticilerine oranla; kat hizmetleri yöneticilerinin ise genel müdürlere oranla daha fazla iş yükü algıladıkları belirlenmiştir. Kat hizmetleri ve yiyecek içecek departmanlarındaki fiziksel çabanın diğer departmanlara nazaran daha fazla olduğu göz önünde bulundurulduğunda, çalışanlara ilişkin algılara benzer olarak yöneticilere ilişkin algılarda da farklılaşmanın ortaya çıktığı düşünülmektedir. Zihinsel faktörler bakımından ise genel müdürlerin ön büro müdürleri ve yiyecek içecek müdürlerine oranla daha fazla iş yükü algıladıkları belirlenmiştir. Genel müdürlerin otelde doğrudan işin fiilen yerine getirilmesinden ziyade, işi planlayan, organize eden, çalışanları yönlendiren, koordinasyonu sağlayan ve denetimi gerçekleştiren kişiler olduğu düşünüldügüunde (Akoğlan Kozak, 2014, s.15), en fazla zihinsel iş yükünün genel müdürlerde görülmesi beklenen bir durumdur.

Yöneticilerin eğitim durumları ile ilgili farklılıklara bakıldığında (Tablo 8), duygusal çaba faktörleri bakımından çalışanlardan farklı olarak lise ve lisans mezunu yöneticilerin daha fazla iş yükü algıladıkları ve yine çalışanlardan farklı olarak zihinsel faktörler bakımından lisans mezunu yöneticilerin lisansüstü mezunu yöneticilerden daha fazla iş yükü algıladıkları belirlenmiştir. Son olarak zihinsel faktörler bakımından ilköğretim mezunu yöneticilerin lisans mezunu yöneticilere oranla daha fazla iş yükü algıladıkları görülmektedir. Duygusal çaba faktörleri ve zihinsel faktörler bağlamında değerlendirildiğinde, yöneticilerde eğitim seviyesi arttıkça iş yükü algısının artması durumunun, eğitim seviyesindeki artışa paralel olarak görev ve sorumluluklardaki artıştan kaynaklandığı düşünülmektedir.

Tablo 9. Iş̧ükü Faktörlerinin Yöneticilerin Yaşlarına ve Işs Tecrübelerine Göre Değişimi

\begin{tabular}{|c|c|c|c|c|c|c|c|c|}
\hline & \multicolumn{4}{|c|}{ Yaş } & \multicolumn{4}{|c|}{ İș Tecrübesi } \\
\hline & & Ort. & P Değ. & Fark & & Ort. & P Değ. & Fark \\
\hline $\begin{array}{l}\text { Duygusal } \\
\text { Çaba Fkt. }\end{array}$ & $\begin{array}{l}21-26 \text { yaş (a) } \\
27-32 \text { yaş (b) } \\
33-38 \text { yaş (c) } \\
39-44 \text { yaş (d) } \\
45 \text { yaş ve üzeri (e) }\end{array}$ & $\begin{array}{l}2,84 \\
2,70 \\
2,95 \\
2,94 \\
3,03\end{array}$ & ,764* & - & $\begin{array}{l}1-4 \text { y1l } \\
5-9 \text { yil } \\
10-14 \text { y1l } \\
15-19 \text { y1l } \\
20 \text { y1l ve üzeri }\end{array}$ & $\begin{array}{l}2,69 \\
2,72 \\
3,13 \\
2,60 \\
2,93\end{array}$ & ,278* & - \\
\hline Fiziksel Fkt. & $\begin{array}{l}21-26 \text { yaş (a) } \\
27-32 \text { yaş (b) } \\
33-38 \text { yaş (c) } \\
39-44 \text { yas (d) } \\
45 \text { yaş ve üzeri (e) }\end{array}$ & $\begin{array}{l}3,17 \\
3,22 \\
3,20 \\
2,86 \\
2,63\end{array}$ & ,489* & - & $\begin{array}{l}1-4 \text { yil } \\
5-9 \text { yil } \\
10-14 \text { y1l } \\
15-19 \text { yıl } \\
20 \text { yil ve üzeri }\end{array}$ & $\begin{array}{l}2,97 \\
3,11 \\
3,42 \\
3,45 \\
2,56\end{array}$ & ,031* & c>e \\
\hline Zihinsel Fkt. & $\begin{array}{l}21-26 \text { yaş (a) } \\
27-32 \text { yaş (b) } \\
33-38 \text { yaş (c) } \\
39-44 \text { yaş (d) } \\
45 \text { yaş ve üzeri (e) }\end{array}$ & $\begin{array}{l}4,07 \\
4,07 \\
4,27 \\
4,05 \\
4,27\end{array}$ & ,786* & - & $\begin{array}{l}1-4 \text { y1l } \\
5-9 \text { yil } \\
10-14 \text { y1l } \\
15-19 \text { y1l } \\
20 \text { y1l ve üzeri }\end{array}$ & $\begin{array}{l}4,07 \\
4,17 \\
4,10 \\
4,12 \\
4,02\end{array}$ & ,976** & - \\
\hline $\begin{array}{l}\text { Konumsal } \\
\text { Fkt. }\end{array}$ & $\begin{array}{l}21-26 \text { yaş (a) } \\
27-32 \text { yaş (b) } \\
33-38 \text { yaş (c) } \\
39-44 \text { yaş (d) } \\
45 \text { yaş ve üzeri (e) }\end{array}$ & $\begin{array}{l}2,97 \\
2,65 \\
3,02 \\
2,20 \\
3,13\end{array}$ & ,153* & - & $\begin{array}{l}1-4 \text { y1l } \\
5-9 \text { yil } \\
10-14 \text { yil } \\
15-19 \text { y1l } \\
20 \text { y1l ve üzeri }\end{array}$ & $\begin{array}{l}2,56 \\
2,64 \\
3,14 \\
3,60 \\
2,26\end{array}$ & ,044* & $\begin{array}{l}\text { c }>a \\
c>e \\
d>a \\
d>e\end{array}$ \\
\hline $\begin{array}{l}\text { Çevresel } \\
\text { Fkt. }\end{array}$ & $\begin{array}{l}21-26 \text { yaş (a) } \\
27-32 \text { yaş (b) } \\
33-38 \text { yaş (c) } \\
39-44 \text { yaş (d) } \\
45 \text { yaş ve üzeri (e) }\end{array}$ & $\begin{array}{l}2,60 \\
2,87 \\
3,24 \\
2,82 \\
2,56\end{array}$ & ,294* & - & $\begin{array}{l}1-4 \text { yil } \\
5-9 \text { yil } \\
10-14 \text { yıl } \\
15-19 \text { yıl } \\
20 \text { y1l ve üzeri }\end{array}$ & $\begin{array}{l}2,58 \\
2,85 \\
2,95 \\
3,45 \\
3,16\end{array}$ &, $001 *$ & $\begin{array}{l}\text { d }>a \\
\text { d }>b\end{array}$ \\
\hline
\end{tabular}

\footnotetext{
* Varyansların eșitliği varsayımı sağlandığından LSD testi sonuçları baz alınarak değerlendirme yapılmıștır.
} 
Tablo 9'dan izleneceği gibi yöneticilerin algılarına yaş grupları itibariyle bakıldığında, iş yükünde herhangi bir farklılaşma olmadığı görülmektedir $(\mathrm{p}>0,05)$. Bu sonucun araştırma kapsamındaki yöneticilerin en fazla 27-32 yaş grubunda olması $(n=39)$ ve iş yükü algılamalarının ortalama değerlerde olması ile ilişkili olduğu düşünülmektedir. Bu bağlamda, fiziksel ve zihinsel kapasitenin yaş ilerledikçe giderek azaldığ göz önünde bulundurulduğunda, 45 yaş ve üzeri yöneticilerin iş yükü algılarının daha fazla olması beklenirken, sonuçların farklı çıkması genç yöneticilerin enerjilerine, yetişkinlerin ise deneyimli olmalarına bağlanabilir.

Yöneticilerin iș tecrübelerine ilișkin farklılıklar incelendiğinde (Tablo 9), fiziksel faktörler bakımından 10-14 yıl arası çalışanların 20 yıl ve üzeri çalışanlara oranla daha fazla iş yükü algıladıkları belirlenmiştir. Sonuç değerlendirildiğinde, yöneticilerde iş tecrübesi arttıkça fiziksel iş yükünü azaldığ 1 söylenebilir. Konumsal faktörler açısından, 10-14 yıl arası çalışan yöneticilerin 1-4 yıl ve 20 yıl ve üzeri çalışanlara oranla; yine benzer şekilde 15-19 yıl arası çalışanların 1-4 yıl ve 20 yıl ve üzeri çalışanlara oranla daha fazla iş yükü algıladıkları belirlenmiştir. Bu durumda ise yöneticilerin çok fazla veya çok az iş tecrübelerinin olmasının konumsal iş yüklerini arttırdığı söylenebilir. Son olarak çevresel faktörler değerlendirildiğinde, 15-19 yıl aralığında tecrübesi olan yöneticilerin, 1-4 yıl ve 5-9 yıl aralığında tecrübesi olan yöneticilere oranla daha fazla iş yükü algıladıkları belirlenmiştir. Bu durumda ise iş tecrübesi arttıkça çevresel iş yükü algısının da arttığı söylenebilir.

Faktörler bağlamında iş yükü algısından farklı olarak çalışmada ayrı bir ifade ile çalışan ve yöneticilerin genel olarak iş yüklerini ne derecede algıladıkları belirlenmeye çalışılmıştır (Tablo 10). Çalışan ve yöneticilerin genel iş yükü algılarına bakıldığında, hem çalışan hem de yöneticilerin iş yükü algılamalarının ne çok fazla ne de çok az olduğu görülmektedir. Bu durum, Eskişehir'deki otel yönetici ve çalışanlarının genelde işlerini çok ağır olarak algılamadıklarına işaret etmektedir.

Tablo 10. Çalışan ve Yöneticilerin Genel İ̧̧ Yükü Algılarına Iliş̧kin Bulgular

\begin{tabular}{|l|l|l|l|l|}
\hline \multirow{2}{*}{ Genel İş Yükü AlgıSı } & \multicolumn{2}{|c|}{ ÇALIŞAN } & \multicolumn{2}{c|}{ YÖNETICI } \\
\cline { 2 - 5 } & Ortalama & St.Sapma & Ortalama & St.Sapma \\
\hline 27. Soru: İş yükümün çok fazla olduğunu düşünüyorum. & 3,35 & 1,28 & 3,38 & 1,25 \\
\hline
\end{tabular}

Çalışanların genel algıları ile demografik özellikleri arasındaki ilişki incelendiğinde en fazla iş yükünü evli çalışanların algıladıkları görülmüştür. Departmanlar bakımından yiyecek içecek ve kat hizmetleri departmanları çalışanlarının ön büro departmanı çalışanlarından; aynı zamanda kat hizmetleri departmanlarının diğer departman çalışanlarından daha fazla iş yükü algıladıkları belirlenmiştir. Egitim durumu bakımından ise ilköğretim mezunu çalışanların genel iş yükü algılamalarının ön lisans ve lisans mezunu çalışanlardan daha fazla olduğu saptanmıştır. Son olarak 39-44 yaş grubunun 21-26 yaş grubundan; $15-19$ yll iş tecrübesi olan çalışanların ise 1-4 yıl iş tecrübesi olan çalışanlardan daha fazla genel iş yükü algıladıkları belirlenmiştir. Yöneticilere ilişkin veriler incelendiğinde ise genel algılamala ile yalnızca eğitim durumu arasında farklılık saptanmıştır. Lise ve lisans mezunu yöneticilerin genel iş yüküne ilişkin algılarının ilköğretim mezunlarından daha fazla olduğu belirlenmiştir. Gerek yöneticiler gerekse çalışanların genel iş yükü algılamaları ile ilgili edilen bu bulguların faktörler bağlamındaki bulgular ile benzer olduğu görülmektedir.

Çalışmada daha sonra insan kaynakları yönetimi fonksiyonları bakımından iş yükünün kullanımını belirlemek amacıyla faktör analizi yapılmıştır. $\mathrm{Bu}$ bağlamda, alınan uzman görüşleri ve ilgili literatür doğrultusunda oluşturulmuş insan kaynakları yönetimi fonksiyonlarını içeren her bir gruba temel bileșen- 
Tablo 11. Çalışan ve Yöneticilerin Genel İş Yükü Algısının Demografik Özelliklerine Göre Değişimi

\begin{tabular}{|c|c|c|c|c|c|c|c|c|}
\hline \multirow[t]{2}{*}{ Değiş̧ken } & \multicolumn{4}{|c|}{ ÇALIŞAN } & \multicolumn{4}{|c|}{ YÖNETİCI } \\
\hline & Kategori & Ort & $\begin{array}{l}\text { P. } \\
\text { Değ. }\end{array}$ & Fark & Kategori & Ort & $\begin{array}{l}\mathbf{P} \\
\text { Değ. }\end{array}$ & Fark \\
\hline Cinsiyet & $\begin{array}{l}\text { Kadın (a) } \\
\text { Erkek (b) }\end{array}$ & $\begin{array}{l}3,40 \\
3,36\end{array}$ & ,799* & - & $\begin{array}{l}\text { Kadın } \\
\text { Erkek }\end{array}$ & $\begin{array}{l}3,29 \\
3,39\end{array}$ & ,716* & - \\
\hline $\begin{array}{l}\text { Medeni } \\
\text { Durum }\end{array}$ & $\begin{array}{l}\text { Bekar (a) } \\
\text { Evli (b) }\end{array}$ & $\begin{array}{l}3,27 \\
3,60\end{array}$ & $\begin{array}{l}, 045 \\
* *\end{array}$ & $b>a$ & $\begin{array}{l}\text { Bekar } \\
\text { Evli }\end{array}$ & $\begin{array}{l}3,23 \\
3,55\end{array}$ &, $242 *$ & - \\
\hline $\begin{array}{l}\text { Turizm } \\
\text { Eğitimi }\end{array}$ & $\begin{array}{l}\text { Almış } \\
\text { Almamış }\end{array}$ & $\begin{array}{l}3,34 \\
3,41\end{array}$ & ,658* & - & $\begin{array}{l}\text { Almış } \\
\text { Almamış }\end{array}$ & $\begin{array}{l}3,50 \\
3,19\end{array}$ & ,261* & - \\
\hline Dept. & $\begin{array}{l}\text { On Büro (a) } \\
\text { Yiyecek-İçecek (b) } \\
\text { Kat Hizmetleri (c) } \\
\text { Diğer Departmanlar (d) }\end{array}$ & $\begin{array}{l}3,10 \\
3,47 \\
3,71 \\
2,25\end{array}$ & $\begin{array}{l}, 005 \\
* *\end{array}$ & $\begin{array}{l}b>a \\
c>a \\
c>d\end{array}$ & $\begin{array}{l}\text { Genel Müdürler (a) } \\
\text { İnsan Kaynakları Md/Şefleri (b) } \\
\text { Ön Büro Md/Şefleri (c) } \\
\text { Yiyecek-İçecek Md/Şefleri (d) } \\
\text { Kat Hizmetleri Md/Şefleri (e) } \\
\text { Diğer Departman Md/Şefleri (f) }\end{array}$ & $\begin{array}{l}3,16 \\
3,09 \\
3,14 \\
3,67 \\
3,63 \\
2,50\end{array}$ & ,357* & - \\
\hline $\begin{array}{l}\text { Eğitim } \\
\text { Durumu }\end{array}$ & $\begin{array}{l}\text { İlköğretim (a) } \\
\text { Lise (b) } \\
\text { Ön Lisans (c) } \\
\text { Lisans (d) } \\
\text { Lisans Üstü (e) }\end{array}$ & $\begin{array}{l}3,79 \\
3,40 \\
3,16 \\
3,19 \\
3,33 \\
\end{array}$ & $\begin{array}{l}, 034 \\
* *\end{array}$ & $\begin{array}{l}a>c \\
a>d\end{array}$ & $\begin{array}{l}\text { İlköğretim (a) } \\
\text { Lise (b) } \\
\text { Ön Lisans (c) } \\
\text { Lisans (d) } \\
\text { Lisans Üstü (e) }\end{array}$ & $\begin{array}{l}2,00 \\
3,72 \\
3,50 \\
3,37 \\
3,00 \\
\end{array}$ & ,017* & $\begin{array}{l}b>a \\
d>a\end{array}$ \\
\hline Yaş & $\begin{array}{l}15-20 \text { yaş (a) } \\
21-26 \text { yaş (b) } \\
27-32 \text { yaş (c) } \\
33-38 \text { yaş (d) } \\
39-44 \text { yaş (e) } \\
45-50 \text { yaş (f) } \\
51 \text { ve üzeri (g) }\end{array}$ & $\begin{array}{l}3,34 \\
3,20 \\
3,50 \\
3,44 \\
3,81 \\
3,75 \\
3,66 \\
\end{array}$ & $\begin{array}{l}, 036 \\
* *\end{array}$ & $\mathrm{e}>\mathrm{b}$ & $\begin{array}{l}21-26 \text { yaş (a) } \\
27-32 \text { yaş (b) } \\
33-38 \text { yaş (c) } \\
39-44 \text { yaş (d) } \\
45 \text { yaş ve üzeri (e) }\end{array}$ & $\begin{array}{l}3,42 \\
3,30 \\
3,85 \\
3,10 \\
2,66\end{array}$ &, $361^{*}$ & - \\
\hline $\begin{array}{l}\text { İş } \\
\text { Tecrübesi }\end{array}$ & $\begin{array}{l}1-4 \text { yil (a) } \\
5-9 \text { y1l (b) } \\
10-14 \text { y1l (c) } \\
15-19 \text { yil (d) } \\
20 \text { y1l ve üzeri (e) }\end{array}$ & $\begin{array}{l}3,28 \\
3,46 \\
3,62 \\
4,25 \\
4,00\end{array}$ & $\begin{array}{l}, 035 \\
* *\end{array}$ & $d>a$ & $\begin{array}{l}1-4 \text { y1l (a) } \\
5-9 \text { y1l (b) } \\
10-14 \text { y1l (c) } \\
15-19 \text { y1l (d) } \\
20 \text { y1l ve üzeri (e) }\end{array}$ & $\begin{array}{l}3,28 \\
3,37 \\
3,56 \\
3,75 \\
2,50\end{array}$ & ,448* & - \\
\hline
\end{tabular}

* Varyansların eşitliği varsayımı sağlanmamıștır.

** Varyansların eşitliği varsayımı sağlanmıştır.

ler yöntemi kullanılarak faktör analizi uygulanmıştır. Analiz sonucu dağılımın normallik gösterdiği, Bartlett Küresellik Testi sonuçlarının $(1877,736)$ ve KMO değerlerinin anlamlı olduğu $(\mathrm{p}<, 000)$ belirlenmiştir. Daha sonra ise her bir boyut için ifadeler arası korelasyonlar incelenmiş ve ,30'un altında faktör yükü olan planlamaya, iş değerlemeye ve performans değerlemeye ilişkin l'er ifade çıkartılmıştır. Faktör analizi sonucu elde edilen veriler Tablo 12'deki gibidir.

Tablo 12 incelendiğinde, varyansın \%61,76'sı 'Kariyer Yönetimi' olarak adlandırılan birinci faktör, \%61,28’i 'Insan Kaynakları Planlama' olarak adlandırılan ikinci faktör, \%53,72'si 'İş Güvenliği’ olarak adlandırılan üçüncü faktör, \%52,65’i 'Ücret Yönetimi' olarak adlandırılan dördüncü faktör, $\% 48,10$ 'u 'İș Değerleme' olarak adlandırılan beşinci faktör, \%44,97'si 'Performans Değerleme' olarak adlandırılan altıncı faktör ve \%34,09'u 'Çalışan İlişkileri' olarak adlandırılan yedinci faktör olarak açılklanmıştır. Elde edilen sonuçlar insan kaynakları yönetimi fonksiyonları bağlamında yöneticilerin iş yükünü kariyer yönetimi ve planlama konularında birincil derecede dikkate aldıklarını; en az ise çalışan ilişkileri konusunda dikkate aldıklarını göstermektedir.

Çalışmada son olarak yöneticilerin insan kaynakları yönetimi fonksiyonlarına yönelik algıları ile genel iş yükü algıları arasındaki ilişkiyi belirlemek amacıyla Pearson korelasyon analizi yapılmıştır (Tablo 13). Analiz sonucunda; yöneticilerin iş yükü algılamaları ile iş güvenliği faktörü arasında anlamlı bir ilişki olduğu belirlenmiş ancak, bu ilişkiye yönelik korelasyon katsayısı göz önünde bulundurulduğunda aradaki ilişkinin ters yönlü ve zayıf olduğu görülmüştür. 
Tablo 12. İnsan Kaynakları Yönetiminde İ̧̧ Yükünün Kullamınına Ilişkin Faktör Analizi Sonuçları

\begin{tabular}{|c|c|c|c|c|}
\hline Faktör ve İfadeler & $\begin{array}{l}\text { Faktör } \\
\text { Yükü }\end{array}$ & $\begin{array}{c}\text { Açılk. } \\
\text { Varyans } \\
\text { (\%) }\end{array}$ & Özdeğer & Ort. \\
\hline $\begin{array}{l}\text { Kariyer Yönetimi } \\
\text { 22.Çalışanların kariyer engellerine takılmalarını önleyici tedbirler alııım. } \\
\text { 20.Uygun pozisyon olması durumunda çalışanların taleplerini dikkate alırım. } \\
\text { 23.İşin zorluk derecesini terfilerde dikkate alııım. } \\
\text { 21.Çalışanların kendilerini geliştirmelerine olanak sağlarım. } \\
\text { 19.Kariyer kararlarında performans sonuçlarına bakarım. }\end{array}$ & $\begin{array}{l}, 835 \\
, 816 \\
, 804 \\
, 777 \\
, 689 \\
\end{array}$ & 61,76 & 3,08 & $\begin{array}{l}4,04 \\
4,32 \\
4,12 \\
4,35 \\
4,10\end{array}$ \\
\hline $\begin{array}{l}\text { İnsan Kaynakları Planlama } \\
\text { 2.Her bir iş için gerekli personel niteliklerinin doğru olmasına özen gösteririm. } \\
\text { 3.İs için gerekli zamanı belirlerken çalışanın iş yaparken harcadığı zamanı göz önünde } \\
\text { bulundururum. } \\
\text { 1.Gelecek sezonda çalışacak personel sayısını belirlerken iş ve görev tanımlarına bakarım. } \\
\text { 4.Doğru sayıda çalşanı belirlemek için müşteri sayısı ve üretim miktarına bakarım. } \\
\text { 5.Personel alımında iş ve görev için uygun kişiyi tercih ederim. }\end{array}$ & $\begin{array}{l}, 853 \\
, 847 \\
, 787 \\
, 732 \\
, 682\end{array}$ & 61,28 & 3,06 & $\begin{array}{l}4,22 \\
4,06 \\
4,13 \\
4,11 \\
4,30\end{array}$ \\
\hline $\begin{array}{l}\text { İș Güvenliği } \\
\text { 30.Düşme vb. kazaların oluşabileceği alanlarda (mutfak, çamaşırhane, depo gibi) uygun } \\
\text { önlemler alırım. } \\
\text { 31.Bulaşıcı hastalıklar, zehirlenmeler gibi konularda gerekli önlemleri alırım. } \\
\text { 32.Çalışanlara düzenli aralıklarla iş güvenliği ile ilgili riskler hakkında bilgi veririm. } \\
\text { 29.Dinlenme molalarını iş yüküne göre ayarlarım. }\end{array}$ & $\begin{array}{l}, 840 \\
, 838 \\
, 751 \\
, 421\end{array}$ & 53,72 & 2,14 & $\begin{array}{l}4,38 \\
4,36 \\
4,15 \\
3,90\end{array}$ \\
\hline 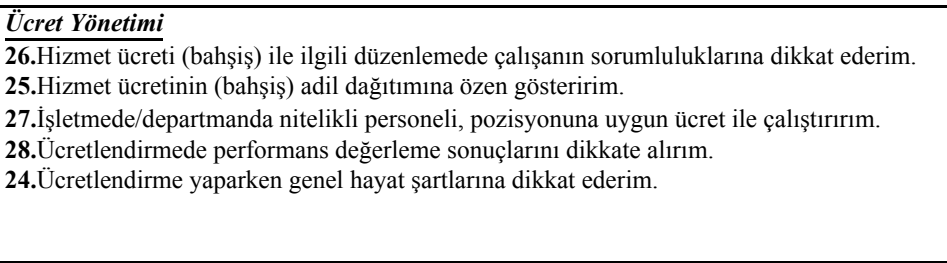 & $\begin{array}{l}, 785 \\
, 779 \\
, 775 \\
, 749 \\
, 497\end{array}$ & 52,65 & 2,63 & $\begin{array}{l}4,15 \\
4,22 \\
4,33 \\
4,05 \\
3,91\end{array}$ \\
\hline $\begin{array}{l}\text { İş Değerleme } \\
\text { 8.İ̧ değerlemelerinde iş yükünü etkileyebilecek (yetenek, çalışma koşulları vb.) faktörlere } \\
\text { bakarım. } \\
\text { 11.İş değerleme sistemindeki önemli faktörlere güvenirim ve kullanırım. } \\
\text { 9.IŞ değerleme yöntemi belirlenirken 'işe göre çalışan' ilkesinden yararlanırım. } \\
\text { 7.İşe ilişkin yetki ve sorumlulukların belirlenmesinde iş değerleme sisteminden } \\
\text { yararlanırım. } \\
\text { 10.Işletmede iş değerleme sistemi sayesinde 'eşit işe eşit ücret' ödemesi yapılır. } \\
\text { 12.Çalışanlar, işlerinin çok basit olduğunu söylerler. }\end{array}$ & $\begin{array}{l}, 827 \\
, 790 \\
, 764 \\
, 714 \\
, 548 \\
, 428\end{array}$ & 48,10 & 2,88 & $\begin{array}{l}3,97 \\
3,82 \\
4,08 \\
3,77 \\
3,64 \\
3,80\end{array}$ \\
\hline $\begin{array}{l}\text { Performans Değerleme } \\
\text { 16.Performans değerlemede önceden belirlenmiş iş ve görev tanımlarından yararlanırım. } \\
\text { 15.Çalışanları uygun işlere yerleştirirken performans sonuçlarını da dikkate alırım. } \\
\text { 18.Çalışanların performansına göre birtakım özendirici uygulamalara başvururum. } \\
\text { 14.Personeli değerlendirirken iş yüküne dikkat ederim. }\end{array}$ & $\begin{array}{l}, 895 \\
\\
, 775 \\
, 579 \\
, 442\end{array}$ & 44,97 & 2,24 & $\begin{array}{l}4,00 \\
4,12 \\
4,08 \\
3,81\end{array}$ \\
\hline $\begin{array}{l}\text { Çalışan İlişkileri } \\
\text { 36.Çalışanlara yaptıkları iş ile ilgili olarak gereken yetki ve sorumluluğu veririm. } \\
\text { 34.İş ile ilgili istenen görevler zamanında yerine getirilir. } \\
\text { 35.Çalış̧ma saatlerini belirlerken kadınların toplumsal rollerini göz önünde bulundururum. } \\
\text { 38.Çalışanlara kişisel sorunlarının çözümünde yardımcı olurum. } \\
\text { 37.Çalışanlara servis, lojman vb. ek hizmetler verilmesini sağlarım. } \\
\text { 33.Çalışanlar, işlerinden sık sık şikâyet ederler. }\end{array}$ & $\begin{array}{l}, 772 \\
\\
, 655 \\
, 564 \\
\\
, 548 \\
, 510 \\
, 378\end{array}$ & 34,09 & 2,04 & $\begin{array}{l}4,21 \\
\\
3,94 \\
3,87 \\
\\
4,35 \\
3,75 \\
3,51\end{array}$ \\
\hline $\begin{array}{l}\text { Cronbach's Alpha Güvenilirlik Katsayısı (a) } \\
\text { KMO Değeri }\end{array}$ & $\begin{array}{l}, 893 \\
, 748\end{array}$ & & & \\
\hline
\end{tabular}


Tablo 13. İnsan Kaynakları Yönetimi Fonksiyonları ile Yöneticilerin Genel Iş̧ Yükü Algıları Illişkisi

\begin{tabular}{|l|l|l|l|}
\hline İnsan Kaynakları Yönetimi Faktörleri & Örneklem & $\begin{array}{l}\text { Korelasyon } \\
\text { Katsayısı (r) }\end{array}$ & Anlamlılı (p) \\
\hline İnsan Kaynakları Planlaması & 90 &, 037 &, 730 \\
\hline İş Değerleme & 90 &,- 051 &, 636 \\
\hline Performans Değerleme & 90 &,- 004 &, 967 \\
\hline Kariyer Yönetimi & 90 &,, 010 &, 924 \\
\hline Ucret Yönetimi & 90 &,- 036 &, 735 \\
\hline Iş̧ Güvenliği & 90 &,$- 247^{*}$ &, 019 \\
\hline Çalışan İlişkileri & 90 &,- 091 &, 394 \\
\hline
\end{tabular}

*İlişki 0,05 düzeyinde anlamlıdır.

Aralarında ilişki saptanamayan fonksiyonlar bakımindan değerlendirildiğinde yöneticilerin iş yükü algıları çok az veya çok fazla olmadığından dolayı, insan kaynakları yönetimi fonksiyonları ile arasında doğrudan bir ilişki olmadığı düşünülebilir. Diğer yandan, yöneticilerin iş güvenliği faktörüne verdikleri önem arttıkça, iş yükü algısının azaldığı sonucunun ise iş güvenliği konusunun önceden tespit edilemeyen, yasal yaptırımlar gerektiren ve işletme içinde çözümlenemeyen sorunlar oluşturabileceğinden dolayı olduğu düşünülmektedir.

\section{Sonuç}

Çalışmada sonuç olarak, otel çalışanlarının iş yükünü açılayan en önemli faktörün konumsal faktör olduğu ve bu sonucu sırasıyla zihinsel faktörler, çevresel faktörler, duygusal çaba faktörleri ve fiziksel faktörlerin izlediği görülmüştür. Bu sonuca benzer olarak, yapılan bir çalışmada (Ünalan vd., 2006) hastane sekreterlerinin en fazla zihinsel iş yükü algıladıkları görülmüştür. Toplam iş yükü seviyesini belirlemeye yönelik bir çalışmada ise zihinsel ve fiziksel faktörler en önemli faktörler olarak belirlenmiş, daha sonra ise çevresel ve konumsal faktörlerin önemli olduğu ifade edilmiştir (Dağdeviren vd., 2005). Yağmuroğlu vd.nin (2011) inşaat sektörü çalışanlarını örneklem alarak yapmış olduğu çalışmada en önemli iş yükü faktörü fiziksel faktör olarak belirlenirken; bunu zihinsel faktör izlemektedir. Tayland'da metal endüstrisinde çalışan kadınlar üzerinde yapılan bir çalışmada ise (Yoopat vd., 2002) fiziksel faktörlerin, çevresel faktörlere oranla daha fazla iş yükü algısı yarattığı belirlenmiştir. İlgili çalışmalarda da görüldüğü gibi yoğun fiziksel çaba gerektiren sanayi işletmelerinde çalışanlarda en fazla fiziksel iş yükü algılanırken; oteller, hastaneler gibi daha çok hizmet üreten işletmelerde, konumsal ve zihinsel iş yükü daha fazla algılanmaktadır.

İş yükü faktörleri itibariyle algının demografik değişkenler ile ilişkisi incelendiğinde iş yükü algisının gerek yöneticilerde gerekse çalışanlarda en fazla departmanlara göre farklılaştı̆̆ ma sonucunda fiziksel iş yükü algısının en fazla kat hizmetleri ve yiyecek içecek departmanı çalışanlarında olduğu sonucu, ilgili literatürde kat hizmetlerinde yapılan çalışmalarla (Krause vd., 2005; Jing, Fulmer ve Buchholz, 2009) benzerdir. Diğer yandan evli çalışanlarda iş yükünün daha fazla olmasına ilişkin elde edilen bulgular turizm sektöründeki iş-aile çatışması sorunun iş yükü algısı bakımından da yaşandığını göstermektedir. Bunun yanında gerek yöneticilerin gerekse çalışanların eğitim durumuna ilişkin elde edilen veriler eğitim durumunun en fazla konumsal iş yükünde farklılık yarattı̆̆ını ortaya koymaktadır. Bunlara ek olarak Eskişehir'deki yönetici ve çalışanların sektördeki diğer insan kaynağına oranla daha genç olmalarının, yaş ve iş tecrübesine ilişkin bulgularda farklılığa neden olduğu görülmüştür.

Genel iş yükü algısına ilişkin bulgular değerlendirildiğinde çalışanların ve yöneticilerin genel iş yükü algılarının orta düzeyde olduğu belirlenmiştir. $\mathrm{Bu}$ sonuçtan farklı olarak literatürde hemşirelere yönelik olarak yapılan çalışmalarda (Yıldız, 2001; Dede ve Çınar, 2008) hemşirelerin işlerini ağır algıladıkları ortaya çıkmıştır. Sektörel anlamda görülen bu farklılı̆̆ın Eskişehir'deki otel işletmelerinin şehir oteli olması bağlamında şekillendiği görülmektedir. Diğer yandan, Şehir otelciliğinin gerektirdiği dört mevsim faaliyet gösterme ve talep açısından kalitenin daha 
belirleyici olmasına bağlı olarak çalışanların iş yüklerini orta düzeyde ağır işler olarak algıladıkları düşünülmektedir. Genel iş yükü algısına ve genel algının demografik değişkenler ile ilişkisine bakıldığında ise elde edilen bulguların faktörler itibariyle elde edilen bulgular ile benzer çıktığı görülmüştür. Bu sonuç, araştırma sonuçlarının geçerli olduğunu ve daha az tartışılır olduğunu göstermektedir.

İnsan kaynakları fonksiyonlarına ilişkin olarak ise yöneticilerin insan kaynakları yönetimi kapsamında iş yükünü en fazla kariyer yönetimi ve planlama ile ilgili konularda; en az ise çalışan ilişkileri ile ilgili konularda dikkate aldıkları belirlenmiştir. Yöneticilerin iş yükünü en fazla planlama ve kariyer konularında dikkate aldıkları sonucuna rağmen, algılanan konumsal ve zihinsel iş yükünün fazla olması çalışanın niteliklerine uygun görevlerde çalıştırılmaması sorununa işaret etmektedir. Çalışanların iş yükü algısında çıkan bu sonuç, otel işletmelerinde insan kaynaklar1 planlaması konusunda hala eksiklikler olduğunu göstermektedir. Yöneticilerin iş yüküne en az önem verdikleri faktörün çalışan ilişkileri olduğu sonucunun, ilgili literatürde de sıkça değinilen (Özdemir vd., 2005; Keser, 2006; Bolat, 2011) ve iş yükü algısı oluşumunda da önemli unsurlar olan stres, işe bağlılık, iş doyumu, iş-aile çatışması gibi çalışan ilişkilerindeki eksikliklerinden dolayı oluştuğu görülmektedir. Otel yöneticilerinin, insan kaynakları yönetiminde çalışan ilişkileri konusuna daha fazla önem vermeleri durumunda bu sorunların kolayca çözülebileceği düşünülmektedir.

İnsan kaynakları yönetimine ilişkin faktörler ile yöneticilerin iş yükü algıları arasındaki ilişkinin incelendiği alt bölümde ise iş güvenliği faktörü ile genel algı arasında az da olsa bir ilişki saptanmıştır. Bu sonucun, iş güvenliği konusunun yasal yaptırımlar doğurması, önceden kontrol edilemeyen sorunlar oluşturması ve işletme içinde çözümlenememesi gibi nedenlerden dolayı yöneticilerde diğer faktörlere oranla daha fazla baskı yarattığından dolayı ortaya çıktığı düşünülmektedir.

$\mathrm{Bu}$ araştırmanın yalnızca Eskişehir'deki otel işletmeleriyle gerçekleştirilmesi ve evrenin tümüne ulaşılamaması araştırmanın kısıtlılıklarını oluşturmuştur. Bu nedenle elde edilen bulgular yalnızca Eskişehir'de şehir otelciliğinde çalışan çalışanlar ve yöneticileri kapsamıştır.
Çalı̧̧manın, otel yöneticilerine ve ilgili literatüre otel işletmelerinde çalışan ve yöneticilerin iş yükü algılarının ne seviyede olduğunu ve hangi faktörler bağlamında nasıl şekillendiğini belirlemek açısından katkısı olacağı düşünülmektedir. Aynı zamanda, iş yükünü doğrudan insan kaynakları yönetiminin tüm fonksiyonları ile ilişkilendiren bu çalışmanın, otel işletmelerinde insan kaynakları yönetiminde iş yükü bakımından farkındalık yaratacağı ve iş yüküne verilen önemi artıracağı düşünülmektedir. Bu bağlamda yöneticilere iş yükünü planlama ve kariyer dışındaki alanlarda da önemsemeleri, ortalama düzeyde olan çalışan iş yükü algısını, insan kaynağını güçlendirme ve çalışma koşullarında iyileştirmeler yaparak daha azaltmaları önerilebilir. Faktörler ile ilişkili olarak ise yöneticilere, otel içerisinde çeşitli düzenlemeleri yaparak çalışanların konumsal iş yüklerini azaltmaları söylenebilir.

Çalışma sonunda ilgili literatüre otellerdeki iş yükü algısına ilişkin bölgeler itibariyle karşılaştırmalı çalışmalar ve şehir ve resort otellerdeki iş yüklerinin karşılaştırılması çalışmaları önerilebilir. Bunun yanında, turizm sektörü içerisinde yer alan havayolları, seyahat acenteleri gibi farklı alt sektörlerde de iş yükü algılarının karşılaştırılması yapılabilir. İnsan kaynakları yönetiminde iş yükünün kullanımına yönelik olarak ise araştırmacılara iş yükü konusu insan kaynaklarının her bir fonksiyonu itibariyle (ücretlendirme, iş değerleme, perfomans değerleme vb.) ayrı araştırmalar yapilabilir.

\section{Kaynakça}

Adalı, S. (1980). Optimal circular ring sector subject to inequality constraints. Journal de Mécanique Appliquée, 4(2), 131-154.

Akbaba, A., E. Günlü, E. (2009). Otel işletmelerinde işgören bulma, seçme ve eğitim sürecinin stratejik insan kaynakları bakış açısıyla değerlendirilmesi: Beş yıldızlı otellerde bir araştırma, Selçuk Üniversitesi İktisadi ve İdari Bilimler Fakültesi Sosyal ve Ekonomik Araştırmalar Dergisi, 9 (18), 1-25. 
Akçadağ, S., Özdemir, E. (2005). İnsan kaynakları kapsamında 4 ve 5 yıldızlı otel işletmelerinde iş tatmini: İstanbul'da yapılan ampirik bir çalışma. Kocaeli Üniversitesi Sosyal Bilimler Enstitüsü Dergisi, 10 (2), 167-193.

Akoğlan Kozak, M., Güçlü Nergis, H. (2008). Turizm işletmelerinde duygusal çaba faktörlerinin işe alma sürecinde kullanılması üzerine bir araştırma. Anadolu Üniversitesi Sosyal Bilimler Dergisi, 8(2), 39-56.

Akoğlan Kozak, M. (1999). Konaklama sektöründe kariyer planlama yönetimi ve uygulamada karşılaşlan sorunlar üzerine bir araştırma. Anatolia Turizm Araştırmaları Dergisi, 10, 53-66.

Akoğlan Kozak, M. (2001). Konaklama işletmelerinde kariyer planlaması. Eskişehir: Anadolu Üniversitesi.

Akoğlan Kozak, M. (2004). Otel İşletmelerinde İnsan Kaynakları Yönetimi ve Örnek Olaylar. Ankara: Detay Yayıncilık.

Akoğlan Kozak, M. (2009). Otel İşletmelerinde İnsan Kaynakları Yönetimi ve Örnek Olaylar. Ankara: Detay Yayıncilik.

Akoğlan Kozak, M. (2012). Genel Turizm Bilgisi. (Ed: N. Kozak). Eskişehir: Anadolu Üniversitesi Yayınları. Yayın No: 2472.

Akova, O., Iş̧1k, K. (2008). Otel işletmelerinde stres yönetimi: İstanbul'daki beş yıldızlı otel işletmelerinde bir araştırma, Kocaeli Üniversitesi Sosyal Bilimler Enstitüsü Dergisi, 15 (1), 17-44.

Akyay, U. (1998). Örgütlerde Kariyer Geliştirme ve Planlaması: Otel İşletmelerinde Bir Uygulama, Ankara: Gazi Üniversitesi.

Alpar, R. (2014). Uygulamalı İstatistik ve Geçerlik-Güvenilirlik. (3. Baskı). Ankara: Detay Yayıncılık.

Altay, H. (2009). Antakya ve İskenderun otel çalışanlarının tükenmişliği ve iş tatmini üzerine bir araştırma. Mustafa Kemal Üniversitesi Sosyal Bilimler Enstitüsü Dergisi, 6 (12), 1-17.
Arslantürk, Y. (2009). Dört ve beş yıldızlı konaklama işletmelerinde performans değerlendirme: Ankara ili örneği. İşletme Araştırmaları Dergisi, 2, 19-34.

Ashforth, B. E., Humphrey. R. H. (1993). Emotional labor in service roles: The influence of identity. Academy of Management Review, 18 (1), 88-115.

Ataay, İ. (2004). İnsan Kaynakları Yönetimi. (Ed: C. Uyargil). İstanbul: Beta Basım A.Ş.

Aydın Tükeltürk, Ş., Şahin Perçin, N. (2008). Turizm sektöründe kadın çalışanların karşılaştıkları kariyer engelleri ve cam tavan sendromu: Cam tavanı kırmaya yönelik stratejiler. Yönetim Bilimleri Dergisi 6 (2), 113-128.

Babalık, F. (2007). Mühendisler İçin Ergonomi, İşbilim. (2. Baskı). Ankara: Nobel Yayın Dağıtım.

Bahar, E. (2006). Tükenmişlik Sendromu, Otel İşletmelerinde Ön Büro Çalışanlarında Bir Uygulama. Aydın: Adnan Menderes Üniversitesi.

Barutçugil, İ. (2004). Stratejik İnsan Kaynakları Yönetimi. İstanbul: Kariyer Yayıncllk.

Baum, T. (2006). Human resource management for tourism, hospitality and leisure: An international perspective. Avustralya: Thomson.

Benligiray, S. (2006). Insan kaynakları yönetiminin gelişme süreci ve lisansüstü tezler üzerindeki etkisi. Eskişehir: Anadolu Üniversitesi.

Bergin-Seers, S., Jago, L. (2007). Performance measurement in small motels in Australia: Funded by the sustainable tourism co-operative research centre. Tourism and Hospitality Research, 7 (2), 144-155.

Bilgin, L. (1994). Endüstri ve Örgüt Psikolojisi Ders Notları. Eskişehir: Anadolu Üniversitesi.

Bolat, O. İ. (2011). İş yükü, iş kontrolü ve tükenmişlik ilişkisi. Atatürk Üniversitesi İktisadi ve İdari Bilimler Dergisi, 25(2), 87-101. 
Brenner, M., Doherty, E. T., Shipp, T. (1994). Speech measures indicating workload demand. Aviation Space and Environmental Medicine, 65 (1), 21-26.

Brookings, J. B., Wilson, G. F., Swain, C. R. (1996). Psychophysiological responses to changes in workload during simulated air traffic control. Biological Psychology, 42 (3), 361-377.

Brymer, R. A., Perrewe, P. L., Johns, T. R. (1991).Managerial job stres in the hotel industry. Inernationality Journal of Hospitality Management, 10 (1), 47-58.

Büyüköztürk, Ş. (2002). Sosyal bilimler için veri analizi el kitabı. Ankara: Pegem Akademi.

Camkurt, M. Z. (2007). İșyeri çalıșma sistemi ve işyeri fiziksel faktörlerinin iș kazaları üzerindeki etkisi. İş Hukuku ve İktisat Dergisi, 21(6), 80-107.

Can, H., Akgün A., Kavuncubaşı Ș. (1998). Kamu ve Özel Kesimde Personel Yönetimi, Ankara: Siyasal Kitabevi.

Caplan R. D. (1971). Organizational Stress and Individual Strain: A Social Psychological Study of Risk Factors in Heart Disease Among Administrators. Michigan: Michigan Üniversitesi.

Casado, M. A. (1992). Student expectations of hospitality jobs. Cornell Hotel and Restaurant Administration Quarterly, 33(4), 80-82.

Charles, K. R., Marshall, L. H. (1992). Motivational preferences of Caribbean hotel workers: An exploratory study. International Journal of Contemporary Hospitality Management, 4(3).

Christou, E. S. (1999). Hospitality management education in Greece: An exploratory study. Tourism Management, 20(6), 683-691.

Cobb, R. A., Baigrie, R. J., Reece-Smith, H., Faber, R. G. (1989). The workload of a surgical unit in a district general hospital. Annals of the Royal College of Surgeons of England, 71 (5), 299.
Cooper, G. E., Harper Jr, R. P. (1969). The use of pilot rating in the evaluation of aircraft handling qualities (No. AGARD-567). Fransa: Advisory Group for Aerospace Research and Development NeuillySur-Seine.

Çam, S. (2011). İşletmelerde İnsan Kaynakları Planlaması. İstanbul: Hayat Yayın Grubu.

Çekal, N. (2013). Yiyecek içecek işletmelerinde mutfak tasarımında dikkat edilmesi gereken faktörler. E-Journal of New World Sciences Academy. ISSN:1306-3111.

Çelik, M., Çıra, A. (2013). Örgütsel vatandaşlık davranışının iş performansı ve işten ayrılma niyeti üzerine etkisinde aşırı iş yükünün aracılık rolü. Ege Akademik Bakış Dergisi, 13(1), 11-20.

Çiçek, D., Akoğlan Kozak, M. (2005). Kat hizmetlerinde HACCP uygulaması üzerine bir model önerisi. Anatolia Turizm Araștırmaları Dergisi, 16 (1), 31-45.

Çokluk, Ö., Şekercioğlu, G., Büyüköztürk, Ş. (2014). Sosyal Bilimler İçin Çok Değişkenli İstatistik SPSS ve LISREL Uygulamaları. (3. Baskı). Ankara: Pegem Akademi.

Dağdeviren, M., Erarslan, E., Kurt, M. (2005). Çalıșanların toplam iş yükü seviyelerinin belirlenmesine yönelik bir model ve uygulaması. Gazi Üniversitesi Mühendislik ve Mimarlik Fakültesi Dergisi, 20 (4), 517-525.

De Waard, D. (1996). The measurement of drivers' mental workload. Groningen: Groningen Üniversitesi.

Dede, M., Çınar, S. (2008). Dâhiliye yoğun bakım hemşirelerinin karşılaştıkları güçlükler ve iş doyumlarının belirlenmesi. Maltepe Üniversitesi Hemşirelik Bilim ve Sanatı Dergisi, 1 (1), 3-14.

Demir, C., Güzel T. (2005). Konaklama İşletmelerinde İnsan Kaynakları Yönetimi. (Ed: C. Demir). İzmir: Nobel Yayın Dağıtım. 
Dessler, G. (2009). Fundamentals of Human Resource Management. New Jersey: Pearson International Edition.

Dolgun, U. (2003). Girşimcilik. İstanbul: Alfa Yayımcllik.

Dolgun, U. (2010). İnsan Kaynakları Yönetimi. Bursa: Ekin Basım Yayın Dağıtım.

Duman, T., Tepeci, M., Unur, K. (2006). Mersin'de yükseköğretim ve orta öğretim düzeyinde turizm eğitimi almakta çalışma isteklerinin karşılaştırmalı analizi. Anatolia: Turizm Araştırmaları Dergisi, 17 (1), 51-69.

Duru, H. A., Ermiş, A., Akay, D., Kurt, M. (2005). Bilgisayar sektöründe öznel bir yöntemle (NASA-Tlx) zihinsel iş yükünün ölçülmesi. Teknoloji Dergisi, 8 (2), 173-180.

Edworthy, A. (2000). Managing Stress. Buckingham: Open University Press.

Emir, O., Baytok, A. (2004). Otel işletmelerinde iş gören tatmini ve Afyon'da yerleşik yıldızlı oteller örneği. 1. Balıkesir Ulusal Turizm Kongresi.

Erkan, N. (2005). Verimlilik, Sağllk ve Güvenlik İçin İnsan Faktörü Mühendisliği: Ergonomi. Ankara: Milli Prodüktivite Merkezi.

Esmer, İ. (2011). İzmir İlinde Bulunan Dört ve Beş Yıldızlı Otel İşletmelerinin Performans Değerleme ve Geribildirim Sistemlerine Dair Bir Alan Araştırması. Mersin: Mersin Üniversitesi.

Finegold, L. S., Lawless, M. T., Simons, J. L., Dunleavy, A. O., Jonhson, J. (1986). Estimating crew performance in advanced systems,II: Application to future gunship. Bölüm B: Results of data analysis for AC$130 H(R P)$. Kalifornia: Air Force Flight Test Center.

Gavcar, E., Bulut, Z. A., Engin, K. (2006). Konaklama işletmelerinde uygulanan performans değerleme sistemleri ve uygulama alanları (Muğla ili örneği). Yönetim ve Ekonomi Dergisi, 13 (2).
Gawron, V. J. (2008). Human performance, workload, and situational awareness measures handbook. Florida: CRC Press.

Gertsch, P. (1987). Assessment of hospital workload in war surgery. British journal of surgery, 74(9), 831-833.

Grandey, A. A. (2003). When 'the show must go on': Surface acting and deep acting as determinants of emotional exhaustion and peer-rated service delivery. Academy of Management Journal, 46(1), 86-96.

Guastello, S. J. (2006). Human Factors Engineering and Ergonomics. Mahwah, New Jersey: L. Erlbaum Associates.

Güney, S. (2001). Yönetim ve Organizasyon. (Ed: S. Güney) Ankara: Nobel Yayın Dağıtım.

Hart, S. G., Hauser, J. R. (1987). Inflight application of three pilot workload measurement techniques. Aviation, Space, and Environmental Medicine. 58 (5), 402-410.

Hart, S. G. \& Staveland, L. E. (1988). Development of NASA-TLX (Task Load Index): Results of empirical and theoretical research. Advances in Psycho$\log y, 52,139-183$.

Helm, W. R., Donnell, M. L. (1979). Mission Operability Assessment Technique: A System Evaluation Methodology. California: Pacific Missile Test Center Point Mugu.

Hicks, J. W. (1960). Republican Ascendancy, (Ed: K. Bunnell). Washington: American Council on Education.

Hochschild, A. R. (1983). The Managed Heart: Commercialization of Human Feeling. Berkeley: University of California Pres.

Iwakiri, K., Kunisue, R., Sotoyama, M., Udo, H. (2008). Postural support by a standing aid alleviating subjective discomfort among cooks in a forward-bent posture during food preparation. Journal of Occupational Health-English Edition, 50 (1), 57. 
İnce, C. (2008). Toplam kalite yönetimi ve otel işletmelerinde işgören tatminine etkileri. Anatolia: Turizm Araștırmaları Dergisi, 19(1), 57-70.

İncir, G. (2008). Ergonomi, Çalışma Ortamı ve Fiziksel Çevre. Ankara: Yenigün Matbaacılık.

Jing, X., Fulmer, S., Buchholz, B. (2009). Posture, activities, tools, and handling analysis for floor coverers focusing on the knee. Proceedings of the $\mathrm{Hu}$ man Factors and Ergonomics Society Annual Meeting, 53 (18), 1277-1281.

Kalınkara, V., Öktem, Ş. (2002). Otel işletmelerinde mutfak donanımının çalışanlara uygunluğunun ergonomik olarak değerlendirilmesi. Akdeniz Ülkeleri Turizm Kongresi Bildiri Metni, 1 (1), 527-536.

Karakuş, S., Kılınç N. (2006). Postür ve sportif performans. Kastamonu Eğitim Dergisi, 14 (1), 309-322.

Kaynak, T. (1996). İnsan Kaynakları Planlaması. İstanbul: Alfa Basım Yayım Dağıtım.

Keser, A. (2006). Çağrı merkezi çalışanlarında iş yükü düzeyi ile iş doyumu ilişkisinin araştırılması. Kocaeli Üniversitesi Sosyal Bilimler Enstitüsü Dergisi, 11 (1), 100-119.

Kılıç, G., Öztürk, Y. (2010). Kariyer yönetim sistemi ve örgütsel bağlılık arasındaki ilişki: Beş yıldızlı otel işletmelerinde bir araştırma. Ege Academic Review, 10(3), 981-1011.

Kim, H. J. (2008). Hotel service providers' emotional labor: The antecedents and effects on burnout. International Journal of Hospitality Management, 27(2), 151-161.

Kramer, A. F. (1991). Physiological metrics of mental workload: A review of recent progress (Ed: D. L. Damos). London: Taylor and Francis.

Krause, N., Scherzer, T., Rugulies, R. (2005). Physical workload, work intensification, and prevalence of pain in low wage workers: results from a participatory research project with hotel room cleaners in Las Vegas. American Journal of Industrial Medicine, 48 (5), 326-337.
Krause, N., Scherzer, T., Rugulies, R. (2005). Physical workload, work intensification, and prevalence of pain in low wage workers: results from a participatory research project with hotel room cleaners in Las Vegas. American Journal of İndustrial Medicine, 48 (5), 326-337.

Krol, J. P. (1971). Variations in ATC-work load as a function of variations in cockpit workload. Ergonomics, 14(5), 585-590.

Kurgun, O. A., Alimanoğlu Yemişçi, D. (2007). İş değerlemede puanlama yöntemi ve büyük ölçekli bir otel işletmesinde uygulama. Çimento İşveren, 4-15.

Kuşluvan, Z., Kuşluvan, S. (2005). Otel işletmelerinde iş ve işletme ile ilgili faktörlerin işgören tatmini üzerindeki görece etkisi: Nevşehir örneği. Anatolia: Turizm Araştırmaları Dergisi, 16 (2), 183-203.

Ladkin, A., Riley, M. (1996). Mobility and structure in the career paths of UK hotel managers: A labour market hybrid of the bureaucratic model?. Tourism Management, 17 (6), 443-452.

Leka, S., Cox, T. (2008). PRIMA-EF Guidance on the European Frameworkfor Psychosocial Risk Management: A Resource for Employers and Worker Representatives. Genova: WHO Protecting Workers' Health Series.

Lowy, A., Brazier, J., Fall, M., Thomas, K., Jones, N. \& Williams, B. T. (1993). Minor surgery by general practitioners under the 1990 contract: effects on hospital workload. BMJ: British Medical Journal, 307(6901), 413.

Luecke, R. (2010). Performans Yönetimi. (Çev: A. Özer). İstanbul: İş Bankası Yayınları.

Lysaght, R. J., Hill, S. G., Dick, A. O., Plamondon, B. D., Linton, P. M. (1989). Operator workload: Comprehensive review and evaluation of operator workload methodologies. Amerika: United States Army Research Institute for the Behavioral and Social Sciences. 
Meister, D. (1986). Human factors testing and evaluation, 5. Amsterdam: Elsevier.

Messing, K., Chatigny, C., Courville, J. (1998). Light and heavy work in the housekeeping service of a hospital. Applied ergonomics, 29 (6), 451-459.

Miller, S. (2001). Literature Review Workload Measures, Amerika: Iowa Üniversitesi. Belge no: N01-006.

Mirze, S. K. (2010). İşletme. İstanbul: Literatür Yayıncllik.

Morris, J. A., Feldman, D. C. (1996). The dimensions, antecedents, and consequences of emotional labor. Academy of management review, 21 (4), 986-1010.

Muckler, F. A., Seven, S. A. (1992). Selecting performance measures: 'Objective versus subjective' measurement. Human Factors: The Journal of the Human Factors and Ergonomics Society, 34 (4), 441-455.

Mulder, G. (1979). Sinus arrhythmia and mental workload. Mental workload: Its theory and Measurement, 8, 327-343.

Newton, J. N., Seagroatt, V., Goldacre, M. (1994). Geographical variation in hospital admission rates: An analysis of workload in the Oxford region, England. Journal of Epidemiology and Community Health, 48 (6), 590-595.

Ng, C. W., Pine, R. (2003). Women and men in hotel management in Hong Kong: perceptions of gender and career development issues. International Journal of Hospitality Management, 22 (1), 85-102.

Olalı, H., Korzay, M., Yavuzer, Z. (1989). Otel İşletmeciliği. Eskişehir: İşletme Fakültesi Yayını. Yayın No: 109.

Ordukaya, H. (2011). İnsanın çalışma hayatındaki yeri, fiziksel iş yükü ve ergonomi, T.C. Bilim, Sanayi ve Teknoloji Bakanlı̆̆ı Verimlilik Genel Müdürlüğü Dergisi, 273-274.

Osmay, N. (2005). Mühendisler İçin Ergonomi: İşbilim. Ankara: Nobel Yayın Dağıtım.
Öğrüç Ildız, G. (2009). İnşaat Firmalarında Proje Müdürlerinin İş Yükü, İş Stresi, İş Tatmini Ve Motivasyon İlişkisi. İstanbul: Kültür Üniversitesi.

Özdemir, B., Aktaş, A., Altıntaş, V. (2005). Turizm ve otelcilik eğitimi görmekte olan lisans düzeyindeki öğrencilerin otel işletmelerinin yiyecek-içecek bölümüne yönelik tutumları. Anatolia: Turizm Araşttrmaları Dergisi, 16 (1), 46-58.

Özdemir, E., Akpınar, A. T. (2002). Konaklama işletmelerinde insan kaynakları yönetimi, çerçevesinde Alanya'daki otel ve tatil köylerinde insan kaynaklar1 profili. Kocaeli Üniversitesi Sosyal Bilimler Enstitüsü Dergisi, 3(2), 85-105.

Özel, Ç. H. (2012). Otel İşletmeciliği. (Ed: M. Akoğlan Kozak). Ankara: Detay Yayıncillk.

Özkul, E. (1996). Ergonomi. Eskişehir: Anadolu Üniversitesi Yayınları. Yayın no: 973.

Partlow, C. G. (1996). Human-resources practices of TQM hotels. The Cornell Hotel and Restaurant Administration Quarterly, 37(5), 67-77.

Pearson, R. G., Byars Jr, G. E. (1956). The development and validation of a checklist for measuring subjective fatigue (No. SAM-56-115). Teksas: School of Aviation Medicine Randolph Afb.

Pitrella, F. D., Kappler, W. D. (1988). Identification and evaluation of scale designing principles in the development of the sequential judgement, extended range scale. Watchberg: Forschungsititut dur Anthropotechnick, FAT. Rapor No: 80.

Pulat, B. M. (1997). Fundamentals of Industrial Ergonomics. İngiltere: Waveland Press.

Rafaeli, A., R. Sutton. (1987). Expression of emotion as part of the work role. Academy of Management Review, 12, 23-37.

Roscoe, A. H. (1978). Stress and workload in pilots. Aviation, space, and environmental medicine, 49, 630-636. 
Roscoe, A. H. (1984). Assessing pilot workload in flight. İngiltere: Royal Aircraft Establishment Bedford.

Roscoe, A. H. (1992). Assessing pilot workload - Why measure heart-rate, Hrv and respiration. Biological Psychology, 34(2-3), 259-287.

Saaty, T. L. (1980). The Analytic Hierarchy Process: Planning, Priority Setting, Resources Allocation. New York: McGraw.

Sağın, S.K. (1986). Ergonomik çalışma yeri düzenlemesi. Mühendis ve Makine Dergisi, 27(323).

Sainsbury, R., Haward, R., Round, C., Rider, L., Johnston, C. (1995). Influence of clinician workload and patterns of treatment on survival from breast cancer. The Lancet, 345(8960), 1265-1270.

Saldamlı, D. A. (2013). Otel işletmelerinde stres kaynakları ve çalışanlar üzerindeki etkileri: Beş yıldızlı otellerde bir uygulama. Çukurova Üniversitesi Sosyal Bilimler Enstitüsü Dergisi, 6(6).

Seymour, D. (2000). Emotional labour: A comparison between fast food and traditional service work. International Journal of Hospitality Management, 19(2), 159-171.

Shacham, S. (1983). A shortened version of the Profile of Mood States. Journal of Personality Assessment, 47 (3), 305-306.

Sheridan, T. B., Simpson, R. W. (1979). Toward the definition and measurement of the mental workload of transport pilots. Cambridge, Massachusets: Massachusetts Institute of Technology.

Sheridan, T. B., Stassen, H. G. (1979). Definitions, Models and Measures of Human Workload. Amerika: Springer, 219-233.

Sheridan, T. B. (1980). Mental workload: What is it? Why bother with it. Human Factors Society Bulletin, 23(2), 1-2.

Solmuş, T. (2004). İş Yaşamında Duygular ve Kişilerarası İlişkiler. İstanbul: Beta Basım.
Sökmen, A. (2005). Konaklama işletmeleri yöneticilerinin stres nedenlerinin belirlenmesinde cinsiyet faktörü: Adana'da ampirik bir araştırma. AİBÜ-İIBF Ekonomik ve Sosyal Araştırmalar Dergisi. 1, 1-27.

Stecklein, J. E. (1974). Approaches to measuring workload over the past two decades. New Directions for Institutional Research, 1974(2), 1-16.

Su, B. A. (2001). Ergonomi. Ankara: At1lım Üniversitesi Yayınları. Yayın no: 5.

Şimşek, M. (1994). Mühendislikte Ergonomik Faktörler. İstanbul: Marmara Üniversitesi Yayınları. Yayın no: 547.

Şimşek, M. Ş., Akgemici, T., Çelik A. (2003). Davranış Bilimlerine Giriş ve Örgütlerde Davranış. Konya: Adım Matbaacilık.

Tayfun, A. (1996). Otel İşletmelerinde İsgören Etkinliğinin Araştırılmasında Bir Faktör Olarak İs Değerlemesi ve Beş Yildızh Otel İşletmelerinde Bir Uygulama (Türkiye Örneği). Ankara: Gazi Üniversitesi.

Tepeci, M., Birdir, K. (2003). Otel çalışanlarında tükenmişlik sendromu., Ulusal Yönetim ve Organizasyon Kongresi Bildirisi, 959-972.

Toker, B. (2011). Demografik değişkenlerin iş tatminine etkileri: İzmir'deki beş ve dört yıldızlı otellere yönelik bir uygulama. Doğuş Üniversitesi Dergisi, 8 (1), 92-107.

Tortop, N., Aykaç, B., Yayman, H., Özer, M.A. (2007). İnsan Kaynakları Yönetimi. Ankara: Nobel Yayın Dağıtım.

Tuncer, M., Yeşiltaş, M. (2013). Çalışma yaşam kalitesinin otel işletmesi çalışanları üzerindeki etkileri. İsletme Araştırmaları Dergisi, 5 (1), 57-78.

Turhan, U. (2001). Hava trafik kontrollerinin performansinda iş yükünün etkileri ve hava trafik kontrolörleri üzerine bir uygulama. Eskişehir: Anadolu Üniversitesi. 
Türkay, O., Eryılmaz, B. (2013). Kariyer değerleri ve kariyer yolu tercihleri ilişkisi: Türk turizm sektöründen örnekler. Sosyal Bilimler Ensitüsü Dergisi, 24, 179-200.

Türkay, O., Ünal, A., Taşar, O. (2012). Motivasyonel ve yapısal etkenler altında duygusal emeğin işe bağlllığa etkisi. Uluslararası Yönetim İktisat ve İşletme Dergisi, 7 (14), 201-222.

Ursin, H., Ursin, R. (1979). Physiological İndicators of Mental Workload. Amerika: Springer, 349-365.

Uyargil C., Özçelik A. O., Adal Z., Sadullah Ö., Ataay İ.D., Dündar G., Acar, A.C., Tüzüner, L. (2008). İnsan Kaynakları Yönetimi. İstanbul: Beta Basım Yayım Dağıtım.

Uygur, A. (1998). Örgütlerde Kariyer Geliştirme ve Planlaması: Otel İşletmelerinde Bir Uygulama. Ankara: Gazi Üniversitesi.

Uzun, Ö., Yiğit, E. (2011). Örgütsel stres ve örgütsel bağlllık ilişkisi üzerine orta kademe otel yöneticileri üzerinde yapılan bir araştırma. Eskişehir Osmangazi Üniversitesi İIBF Dergisi, 6 (1), 181-213.

Ünalan, D., Çetinkaya, F., Özyurt, Ö., Kayabaşı, A. (2006). Bir üniversite hastanesinde çalışan sekreterlerde iş memnuniyeti. Hacettepe Sağ $l k$ İdaresi Dergisi, 9 (1), 1-18.

Vidulich, M. A., Tsang, P. S. (1987). Absolute magnitude estimation and relative judgement approaches to subjective workload assessment. Proceedings of the Human Factors and Ergonomics Society Annual Meeting, 31 (9).1057-1061.

Wierwille, W. W., Casali, J.G. (1983). A validated rating scale for global mental workload measurement applications. Proceedings of the Human Factors Society - 27th Annual Meeting Bildirisi. Virginia: Norfolk.

Wierwille, W. W. (1979). Physiological measures of aircrew mental workload. Human Factors: The Journal of the Human Factors and Ergonomics Society, 21(5), 575-593.
Wierwille, W. W., Rahimi, M., Casali, J. G. (1985). Evaluation of 16 measures of mental workload using a simulated flight task emphasizing mediational activity. Human Factors: The Journal of the Human Factors and Ergonomics Society, 27 (5), 489-502.

Wolf, J. D. (1978). Crew Workload Assessment. Development of a Measure of Operator Workload. Minneapolis: Honeywell Inc Minneapolis Minn Systems And Research Center.

Yağmuroğlu, Z., Günaydın, H. M., Kale, S. (2011). İş gereksinim analizi yönteminin iş güvenliği bağlamında incelenmesi. 3. İşçi Sağlığı ve İş Güvenliği Sempozyumu.

Yeh, Y. Y., Wickens, C. D. (1988). Dissociation of performance and subjective measures of workload. Human Factors: The Journal of the Human Factors and Ergonomics Society, 30 (1), 111-120.

Yenipınar, U. (2005). Konaklama İşletmelerinde İnsan Kaynakları Yönetimi: İlkeler ve Uygulamalar. (Ed: C. Demir). İzmir: Nobel Yayın Dağıtım.

Yıldız, N. (2001). Yoğun Bakım Ünitelerinde Çalışan Hemşirelerde Isş Doyumunu Etkileyen Faktörler. İstanbul: İstanbul Üniversitesi.

Yllmaz, F. (2010). Türkiye’de kadın çalışanların mesleki sağlık ve güvenlik koşulları. Uluslararası Sosyal Araştırmalar Dergisi, 3(13), 268-284.

Yoopat, P., Toicharoen, P., Glinsukon, T., Vanwonterghem, K., Louhevaara, V. (2002). Ergonomics in practice: physical workload and heat stress in Thailand. International Journal of Occupational Safety and Ergonomics, 8 (1), 83-93.

Zhang, H. Q., Wu, E. (2004). Human resources issues facing the hotel and travel industry in China. International Journal of Contemporary Hospitality $\mathrm{Ma}$ nagement, 16 (7), 424-428.

Zohar, D. (1994). Analysis of stress profile in the hotel industry. International Journal of Hospitality Management, 13 (3), 219-231. 